\title{
The effect of assimilating satellite-derived soil moisture data in SiBCASA on simulated carbon fluxes in Boreal Eurasia
}

\author{
M. K. van der Molen ${ }^{1}$, R. A. M. de Jeu ${ }^{2,3}$, W. Wagner ${ }^{4}$, I. R. van der Velde ${ }^{1}$, P. Kolari ${ }^{5}$, J. Kurbatova ${ }^{6}$, A. $\operatorname{Varlagin}^{6}$, \\ T. C. Maximov ${ }^{7}$, A. V. Kononov ${ }^{7}$, T. Ohta ${ }^{8}$, A. Kotani $^{8}$, M. C. Krol ${ }^{1}$, and W. Peters ${ }^{1,9}$ \\ ${ }^{1}$ Meteorology and Air Quality group, Wageningen University, P.O. Box 47, 6700 AA Wageningen, the Netherlands \\ ${ }^{2}$ VU University Amsterdam, Department of Earth Sciences, De Boelelaan 1085, 1081 HV Amsterdam, the Netherlands \\ ${ }^{3}$ Transmissivity B. V., Space Technology Centre, Huygensstraat 34, Noordwijk, the Netherlands \\ ${ }^{4}$ Vienna University of Technology, Department of Geodesy and Geoinformation, Gusshausstrasse 27-29, \\ 1040 Vienna, Austria \\ ${ }^{5}$ Department of Physics, University of Helsinki, P.O. Box 48, Erik Palménin aukio 1, 00014 Helsinke, Finland \\ ${ }^{6}$ A. N. Severtsov Institute of Ecology and Evolution of the Russian Academy of Sciences, Leninsky Prospekt 33, \\ 119071 Moscow, Russia \\ ${ }^{7}$ Institute for Biological Problems of the Cryolithozone, 677980, 41 Lenin Ave., Yakutsk, Republic of Sakha (Yakutia), Russia \\ ${ }^{8}$ Graduate School of Bioagricultural Sciences, Nagoya University, Furo-cho, Chikusa-ku, Nagoya, 464-8601, Japan \\ ${ }^{9}$ Centre for Isotope Research, Energy and Sustainability Research Institute Groningen, Groningen University, \\ Groningen, the Netherlands
}

Correspondence to: M. K. van der Molen (michiel.vandermolen@wur.nl)

Received: 30 June 2015 - Published in Hydrol. Earth Syst. Sci. Discuss.: 4 September 2015

Revised: 21 December 2015 - Accepted: 23 January 2016 - Published: 3 February 2016

\begin{abstract}
Boreal Eurasia is a region where the interaction between droughts and the carbon cycle may have significant impacts on the global carbon cycle. Yet the region is extremely data sparse with respect to meteorology, soil moisture, and carbon fluxes as compared to e.g. Europe. To better constrain our vegetation model SiBCASA, we increase data usage by assimilating two streams of satellite-derived soil moisture. We study whether the assimilation improved SiBCASA's soil moisture and its effect on the simulated carbon fluxes. By comparing to unique in situ soil moisture observations, we show that the passive microwave soil moisture product did not improve the soil moisture simulated by SiBCASA, but the active data seem promising in some aspects. The match between SiBCASA and ASCAT soil moisture is best in the summer months over low vegetation. Nevertheless, ASCAT failed to detect the major droughts occurring between 2007 and 2013. The performance of ASCAT soil moisture seems to be particularly sensitive to ponding, rather than to biomass. The effect on the simulated carbon fluxes is large, 5-10\% on annual GPP and TER, tens of percent on local NEE, and $2 \%$ on area-integrated NEE, which is
\end{abstract}

the same order of magnitude as the inter-annual variations. Consequently, this study shows that assimilation of satellitederived soil moisture has potentially large impacts, while at the same time further research is needed to understand under which conditions the satellite-derived soil moisture improves the simulated soil moisture.

\section{Introduction}

The interest of this publication is to explore the potential of assimilating satellite-derived soil moisture in the vegetation model SiBCASA over Boreal Eurasia with particular focus on the impact on simulated carbon fluxes. In remote regions such as Boreal Eurasia meteorological driver data for vegetation models (temperature, precipitation, etc.) are poorly constrained by surface observations, leaving room for improvement in the soil moisture content simulated in vegetation models. Boreal Eurasia is also a region with large carbon stocks in biomass and vegetation (Schepaschenko et al., 2013; McGuire et al., 2009; Tarnocai et al., 2009), which are 
subject to the fastest climatic change rates on Earth (Goetz et al., 2007), making it a relevant region in the context of ecosystem carbon sequestration. Furthermore, large parts of the region are located in continuous and discontinuous permafrost soils. In the spring, meltwater from the accumulated winter precipitation cannot percolate into the still-frozen soil - it runs off in hilly terrain, and forms ponds on the soil in flat terrain. This causes a bi-modal spatial distribution in soil moisture, with dry hills and wet plains. This process is probably hard to catch by land surface models and satellite observations alike. Satellite-derived soil moisture is observed to have large variability in the northern regions, both within and between different approaches (Mladenova et al., 2014). The derivation of satellite soil moisture is difficult in snow, ice-, and surface-water-rich areas (Högström et al., 2014; Naeimi et al., 2012a). These aspects make a working soil moisture data assimilation system very relevant for vegetation modelling in the region, and challenging. The few tower sites running in the region now have fairly long measurement records, so that they can be used for validation of inter-annual variation (e.g. the 2010 drought). An effort specifically targeted at Boreal Eurasia and carbon fluxes has not been tried before.

Earlier efforts to assimilate satellite-derived soil moisture in vegetation models were often focused on the improvement of soil moisture itself and/or validated with in situ observations over short vegetation in temperate and Mediterranean climate zones (Reichle and Koster, 2005; Reichle et al., 2007; Draper et al., 2009a, b; Miralles et al., 2011b). Other studies focus on the effect on crop yield and carbon fluxes in Europe (Verstraeten et al., 2010; de Wit and van Diepen, 2007; Han et al., 2014). The Global Land Data Assimilation Systems (GLDAS, http://ldas.gsfc.nasa.gov/GLDAS/, see Chen et al., 2013) is worth mentioning here too. Our study is thus the first to assimilate satellite soil moisture in Boreal Eurasia and to evaluate the impact on simulated soil moisture and carbon fluxes with in situ data.

Soil moisture affects vegetation carbon fluxes through photosynthesis and respiration rates. Photosynthesis rates depend on the stomatal conductance, which the plants regulate according to the water potential in the leaf and the atmospheric vapour pressure deficit. The water potential in the leaf is a function of water supply by the roots and the water use by transpiration (Katul et al., 2010). Heterotrophic respiration depends on the soil moisture content, which is the substrate in which microbes and bacteria consume organic matter and release $\mathrm{CO}_{2}$. The dependence of photosynthesis, transpiration, and respiration fluxes on soil moisture is implemented in virtually all contemporary vegetation models via similar types of drought sensitivity functions (Verhoef and Egea, 2014; Sellers et al., 1996; Vetter et al., 2008).

Based on simulations with global climate models, it is expected that global warming is associated with more extreme precipitation regimes, resulting in more frequent and more intense flooding and drought events (Dai, 2011). It is probable that this trend is already becoming visible in the large number of recent droughts, e.g. in Amazonia (2005 and 2010), the US (2008-2012, 2014), European Russia and Siberia (2010, 2013), West Europe (2003), East Africa (2011-2012), Australia (2003-2007), China (2010-2011), as well as floodings in Austria and Germany (2013), Southwest China (2013), India and Pakistan (2014), and the UK (2014). These extremes may have a large effect on the carbon balance of the affected regions, sometimes undoing 10 years of "normal" carbon uptake by natural vegetation and causing crop yield reduction or crop failure (van der Molen et al., 2011; Peters et al., 2010; Reichstein et al., 2007; Ciais et al., 2005).

Soil moisture in land surface models is the balance of precipitation and evaporation, transpiration, runoff, and lateral outflow. Land surface models are often primarily calibrated to simulate water, heat, and carbon exchange with the atmosphere correctly (Williams et al., 2009; Morales et al., 2005), and the water stress function is often one of the functions that is used for calibration. As a result, the absolute value of soil moisture in land surface models, and its variation, has often been subsidiary to simulating exchange fluxes correctly. In the perspective of the expected increasing occurrence of extremes in soil moisture, it is questionable whether this procedure results in satisfactory representation of droughts in land surface models, and their effects on the carbon balances and the disturbance of pools.

Two independent databases of remotely sensed soil moisture have been published recently: the passive microwave soil moisture data set, based on the land parameter retrieval model (LPRM) (Owe et al., 2008), and the active microwave data set, METOP ASCAT 25 (Wagner et al., 1999; Naeimi et al., 2009, 2012b). See Sect. 2.2 for details.

These data sets provide globally consistent, satelliteobserved soil moisture data. As such, they provide ideal soil moisture information to analyse the development of droughts on a regional scale. In this paper, we describe the implementation of a data assimilation system into the land surface model SiBCASA (Schaefer et al., 2008). This scheme adjusts the simulated soil moisture towards the satelliteobserved soil moisture, accounting for the errors in observation and model. We subsequently evaluate the performance of this soil moisture assimilation system by comparing the simulated soil moisture, and the resulting change in carbon fluxes against observations collected at four sites across Boreal Eurasia (defined here as $3^{\circ}<$ latitude $<180^{\circ} \mathrm{E}$ and longitude $>50^{\circ} \mathrm{N}$ ) between 2007 and 2013. Although the in situ observations have limited representability for the $1 \times 1^{\circ}$ latitude/longitude satellite observations, we focus here on longer-term variability (e.g. droughts) which develop over larger areas. We also apply a normalization procedure (CDF matching technique, Sect. 2.3) which removes the impact of soil characteristics on soil moisture distributions. Therefore, the most important reason for mismatch is probably the difference between grid-size average and local precipitation. 

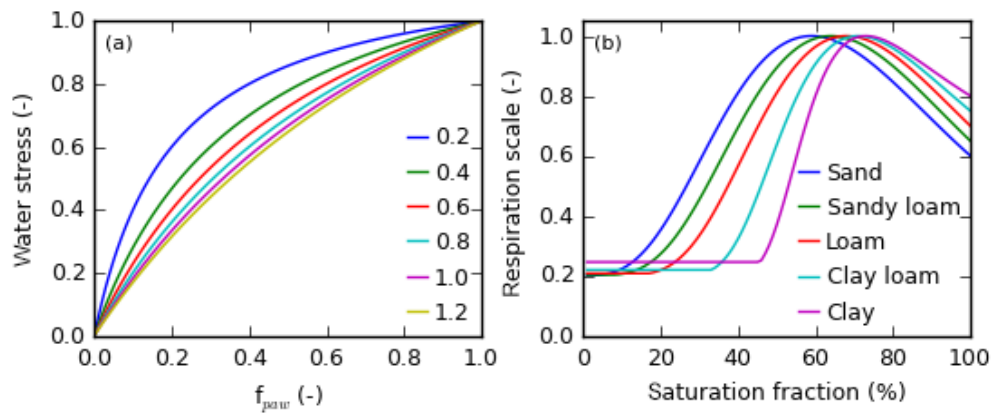

Figure 1. (a) The water stress function in SiBCASA as a function of plant available water fraction. The scaling function is shown for various shape parameters (see legend). The default value for the shape parameter is 0.2 for all biome types. (b) The heterotrophic respiration scaling function in SiBCASA as a function of soil moisture saturation fraction and soil type.

The objective of this paper is therefore to evaluate the use of satellite observed soil moisture for data assimilation in vegetation models in a data-poor region like Boreal Eurasia and to evaluate the impact on the simulated carbon fluxes.

The increasing availability of remote sensing products, e.g. the Soil Moisture and Ocean Salinity mission (SMOS) (Kerr et al., 2001), the Global Change Observation Mission - Water (GCOM-W) (Imaoka et al., 2010; Oki et al., 2010), the Global Land Evaporation: the Amsterdam Methodology (GLEAM) (Miralles, 2011; Miralles et al., 2011b), and the Soil Moisture Active Passive mission (SMAP) (Entekhabi et al., 2010), make this evaluation timely and relevant. If the assimilation of soil moisture proves worthwhile, it may also be applied in other land surface models, e.g. in mesoscale atmosphere models or in agro-meteorological models.

\section{Methods}

\subsection{SiBCASA vegetation model}

SiBCASA is an interactive vegetation-atmosphere model simulating how the growth of vegetation depends on the exchange of water, energy, and carbon between vegetation, atmosphere, and soil (Schaefer et al., 2008). SiBCASA consists of two coupled components, the $\mathrm{SiB}$ component simulates the exchange of heat and water and the uptake of carbon dioxide as a function of temperature, radiation density, humidity, and wind speed, as well as root-zone soil moisture conditions with several time steps per hour (Sellers et al., 1996; Jafarov and Schaefer, 2015). It uses the Farquhar photosynthesis parametrization (Farquhar et al., 1980) in combination with a Ball-Berry type stomatal conductance formulation (Collatz et al., 1991).

The CASA component simulates how the carbon taken up by photosynthesis is allocated to different parts of the vegetation, with specified residence times (Potter et al., 1993). The seasonal development of leaf area index is a function of the amount of carbon allocated to leaves, but the amount of absorbed photosynthetically active radiation (fPAR) is constrained by remote sensing. A more detailed summary of the general features of SiBCASA can be found in van der Velde et al. (2014).

SiBCASA is intended for use as a lower boundary condition for large-scale atmospheric transport models, such as general circulation models and data assimilation systems such as CarbonTracker (Peters et al., 2007). Therefore, it is specifically required to correctly simulate the regional effects of climate variations. In this paper we focus on the role of soil moisture in SiBCASA, with the aim to better describe the effects of climate extremes on the terrestrial carbon dioxide balance. Therefore, we will briefly describe SiBCASA's method of simulating soil water uptake and the relation with stomatal conductance.

SiBCASA is configured with 25 soil layers with a depth up to $15 \mathrm{~m}$ and thicknesses ranging from $2 \mathrm{~cm}$ near the surface to $3 \mathrm{~m}$ at depth. Roots extract water from the part of the soil they penetrate. The plant-available water fraction $\left(f_{\text {paw }}\right)$ is computed as a function of root depth, porosity, wilting point, field capacity, and soil moisture content and varies between wilting point $\left(f_{\text {paw }}=0\right)$ and field capacity $\left(f_{\text {paw }}=1\right)$. The plantavailable water fraction directly influences the photosynthesis capacity by means of the water stress function (Fig. 1), which equals one at field capacity and zero at wilting point. The shape parameter of the soil moisture is 0.2 by default (Fig. 1), implying an aggressive water use strategy, i.e. limited water stress in wet to medium dry soils and accelerating water stress with further drying. At low plant-available water fractions, the photosynthesis capacity is thus reduced by multiplication with the water stress function. This in turn reduces the stomatal conductance.

Soil moisture also affects the turnover times of organic matter in the soil. The turnover times are shortest at an optimal soil moisture saturation fraction (which varies around $60 \%$ of the pore space) and from there increases towards drier and wetter soils (Fig. 1) (Raich et al., 1991). The respiration rates are a function of the carbon pools and turnover times, which are temperature and soil moisture dependent. 
The net effect of soil moisture on Net Ecosystem Exchange (NEE) is the sum of the effect on photosynthesis (GPP, Gross Primary Production) and on respiration rates (TER, Total Ecosystem Respiration).

\subsection{Satellite-derived soil moisture data}

The satellite-observed soil moisture data used in this study come from two independent sources (Liu et al., 2011, 2012): the first is from passive microwave observations, the second from active radar observations. Passive microwave radiation sensors have been on board of various satellite platforms, e.g. Scanning Multichannel Microwave Radiometer (SMMR, 1978-1987), Special Sensor Microwave Imager (SSM/I, 1987-present), Tropical Rainfall Measuring Mission Microwave Imager (TMI, 1997-2015) and the Advanced Microwave Scanning Radiometer - Earth Observing System (AMSR-E, 2002-2011). The retrieval algorithm, the Land Parameter Retrieval Method (LPRM) (De Jeu et al., 2009; De Jeu and Owe, 2003; Owe et al., 2008), is based on a simple radiative transfer equation and used dual-polarized brightness temperature observations in an optimization routine to solve for soil moisture. The retrieved soil moisture is representative for the top few centimetres of the soil. LPRM accounts for the vegetation opacity in the microwave domain. Dense canopies attenuate the microwave signal from the underlying soil surface which results in a lower soil moisture retrieval accuracy. Therefore, the soil moisture retrieval is most reliable for bare and sparsely vegetated areas (de Jeu et al., 2008). As this study is focused on the period 20072013, we use only the AMSR-E data with version v05 of the LPRM with a $50 \mathrm{~km}$ spatial resolution, and a 2-3 day revisit time (Owe et al., 2008).

Complementarily, active radar soil moisture retrievals from the Advanced Scatterometer (ASCAT, 2006-present) in combination with the change detection algorithm is representative for the soil moisture in the top few centimetres (Bartalis et al., 2007; Wagner et al., 1999; Naeimi et al., 2009, 2012b). ASCAT soil moisture retrievals are reliable for sparse and moderately vegetated areas, and less for bare soils (Liu et al., 2012). We use METOP ASCAT25, version WARP5.5, release 2.1 , with a $0.25^{\circ}$ spatial resolution, and a 1-day temporal resolution) (Wagner et al., 1999; Naeimi et al., 2009, 2012b). The period of record of the ASCAT data constrains the study period to 2007-2013.

\subsection{Assimilation method}

The objective of this paper is to attempt an improvement of soil moisture dynamics in SiBCASA by assimilating the passive microwave and/or ASCAT satellite-derived data described above. We use the same assimilation method as used in GLEAM (Miralles et al., 2011a; Miralles, 2011): $d w=K_{t}\left(w_{t}^{\mathrm{obs}}-w_{t}^{\mathrm{sim}}\right)$

with $w_{t}^{x}$ the soil moisture content of the top soil layer, either satellite-observed $(x=$ obs $)$ or simulated $(x=\operatorname{sim}), d w$ the change in $w$ after assimilation. The index $t$ indicates the time in steps of days. $K_{t}$, the Kalman gain, describes how much of the difference $\left(w_{t}^{\mathrm{obs}}-w_{t}^{\mathrm{sim}}\right)$ is applied to $d w$ to update $w^{\mathrm{sim}}$, and depends on the error in the model soil moisture $\sigma^{\operatorname{sim}}$ and the error in the satellite observed soil moisture $\sigma^{\mathrm{obs}}$ :

$K_{t}=\frac{\sigma_{t}^{\operatorname{sim}}}{\sigma_{t}^{\text {sim }}+\sigma_{t}^{\text {obs }}}$.

The error in model soil moisture depends on $d \sigma^{\text {mod }}$, the uncertainty associated with model integration over a time step of one day:

$\sigma_{t}^{\mathrm{mod}}=\sigma_{t-1}^{\mathrm{mod},+}+d \sigma^{\mathrm{mod}}$.

We use a constant $d \sigma^{\text {mod }}=0.01 \mathrm{~m}^{3} \mathrm{~m}^{-3}$ day $^{-1}$. The model soil moisture is updated according to

$w=w+d w$.

When observations were available, the model error $\sigma_{t}^{\bmod }$ is reduced to $\sigma_{t}^{+}$after the assimilation step:

$\sigma_{t}^{\bmod ,+}=\sigma_{t}^{\bmod }\left(1-K_{t}\right)$.

The error or noise in the satellite-observed soil moisture, $\sigma^{\text {obs }}$, depends on the vegetation optical depth, land surface heterogeneity of the pixel, and snow or ice in or on top of the soil, and is output by the retrieval algorithm. The noise is typically of the order of $0.1 \mathrm{~m}^{3} \mathrm{~m}^{-3}$ (standard deviation $\sigma$, e.g. Figs. 5-8).

Since the satellite-observed soil moisture data essentially carry information only about the temporal variations in soil moisture, and not about the absolute value of mean and the amplitude of the variations, we normalize the satellite data (see below) before assimilating the satellite data in $\mathrm{SiB}$ CASA. The entire assimilation procedure consists of the following steps:

- Step 1: run SiBCASA without data assimilation to equilibrium in 2007 and then run until 2013, storing daily model results.

- Step 2: take the spatial average of satellite-derived soil moisture within the $1^{\circ} \times 1^{\circ} \mathrm{SiBCASA}$ grid boxes. Normalize the satellite-observed soil moisture's mean, standard deviation, and higher moments towards the $\mathrm{SiB}$ CASA's soil moisture using the CDF matching technique (Liu et al., 2009, 2012; Reichle and Koster, 2004). We matched the distribution function at every 10th percentile between 10 and 90 . Because the retrieval algorithms do not work under (partially) frozen and snowcovered conditions, we discarded periods with frozen soil in SiBCASA from building the CDF transformation coefficients. 
Table 1. Characteristics of the flux tower sites used in this study.

\begin{tabular}{|c|c|c|c|c|}
\hline Site & Hyytiälä & Tver wet forest & Yakutsk Larix & Elgeeii \\
\hline Latitude & $61^{\circ} 50^{\prime} 51^{\prime \prime} \mathrm{N}$ & $56^{\circ} 26^{\prime} 52^{\prime \prime} \mathrm{N}$ & $62^{\circ} 15^{\prime} 18^{\prime \prime} \mathrm{N}$ & $60^{\circ} 01^{\prime} 01^{\prime \prime} \mathrm{N}$ \\
\hline Longitude & $24^{\circ} 17^{\prime} 37^{\prime \prime} \mathrm{E}$ & $32^{\circ} 54^{\prime} 07^{\prime \prime} \mathrm{E}$ & $129^{\circ} 37^{\prime} 08^{\prime \prime} \mathrm{E}$ & $133^{\circ} 49^{\prime} 53^{\prime \prime} \mathrm{E}$ \\
\hline $\begin{array}{l}\text { Ecosystem } \\
\text { description }\end{array}$ & $\begin{array}{l}\text { taiga } \\
\text { Pinus sylvestris }\end{array}$ & $\begin{array}{l}\text { taiga } \\
\text { Picea, on peat }\end{array}$ & $\begin{array}{l}\text { taiga } \\
\text { Larix cajanderii }\end{array}$ & $\begin{array}{l}\text { taiga } \\
\text { Larix cajanderii }\end{array}$ \\
\hline $\begin{array}{l}\text { Elevation } \\
\text { (m a.s.1.) }\end{array}$ & 181 & 263 & 220 & 202 \\
\hline $\begin{array}{l}\text { Age } \\
\text { (in 2015) }\end{array}$ & 53 & 192 & 185 & 155 \\
\hline Years used & 2007-2013 & 2007-2013 & 2007-2013 & 2010-2013 \\
\hline $\begin{array}{l}\text { Maximum snow } \\
\text { depth }(\mathrm{cm})\end{array}$ & 50 & $50-100$ & 40 & 50 \\
\hline $\begin{array}{l}\text { Maximum LAI } \\
\left(\mathrm{m}^{2} \mathrm{~m}^{-2}\right)\end{array}$ & 2.9 & 3 & 2.1 & 1.4 \\
\hline $\begin{array}{l}\text { Annual } \\
\text { precipitation } \\
(\mathrm{mm})\end{array}$ & 700 & 711 & 230 & 290 \\
\hline $\begin{array}{l}\text { Depth of soil } \\
\text { moisture sensors } \\
\text { used }(\mathrm{cm})\end{array}$ & 2.5 & 10 & 10 & 10 \\
\hline References & $\begin{array}{l}\text { Rannik et al. (2004), } \\
\text { Ilvesniemi et al. } \\
(2010)\end{array}$ & $\begin{array}{l}\text { Kurbatova et al. } \\
\text { (2008), } \\
\text { Milyukova et al. } \\
\text { (2002) }\end{array}$ & $\begin{array}{l}\text { Dolman et al. } \\
(2004) \text {, } \\
\text { Ohta et al. (2008) }\end{array}$ & $\begin{array}{l}\text { Kotani et al. } \\
(2014)\end{array}$ \\
\hline
\end{tabular}

- Step 3: run SiBCASA from equilibrium in 2007 until 2013 with assimilation of the satellite-derived soil moisture.

- Step 4: evaluate the simulated soil moisture, water, and carbon fluxes with in situ flux tower data as described in Sect. 2.4.

\subsection{In situ flux tower data}

For evaluation of the model results, particularly the carbon fluxes, we use 25 site-years of data from four flux tower sites in Boreal Eurasia available in the period 2007-2013 (Table 1). The sites vary in vegetation type, continentality, and permafrost. Flux data were taken in Siberia at more locations, although predominantly in the period 1997-2005, when the ASCAT satellite was not yet launched (Dolman et al., 2012). The sites are in Hyytiälä, Finland (Ilvesniemi et al., 2010; Kolari et al., 2009; Mammarella et al., 2009; Rannik et al., 2004), Tver, European Russia (Kurbatova et al., 2008; Milyukova et al., 2002), Yakutsk, East Siberia (Dolman et al., 2004; Ohta et al., 2008), and Elgeeii, East Siberia (Kotani et al., 2014). The eddy covariance data have been processed according to the harmonized LaThuille FLUXNET database (Baldocchi et al., 2001; Reichstein et al., 2005; Papale et al., 2006; Moffat et al., 2007). All sites are covered with needle leaf forests, evergreen in the western sites, and deciduous in the eastern sites. The stations Yakutsk and Elgeeii are on permafrost and have maximum snow depths of the order of 40 and $50 \mathrm{~cm}$, respectively.

\section{Results}

We will first evaluate the spatial coherence between the simulated and satellite-observed soil moisture, then the temporal coherence. All satellite and in situ data are CDF-matched to the SiBCASA soil moisture. Next, we will compare model and satellite soil moisture data with in situ observations. Finally, we will evaluate the impact of satellite soil moisture assimilation on the simulated carbon fluxes.

\subsection{Reliability of passive microwave and ASCAT soil moisture in Boreal Eurasia}

The spatial coherence between SiBCASA and satelliteobserved soil moisture is studied by comparing maps of 

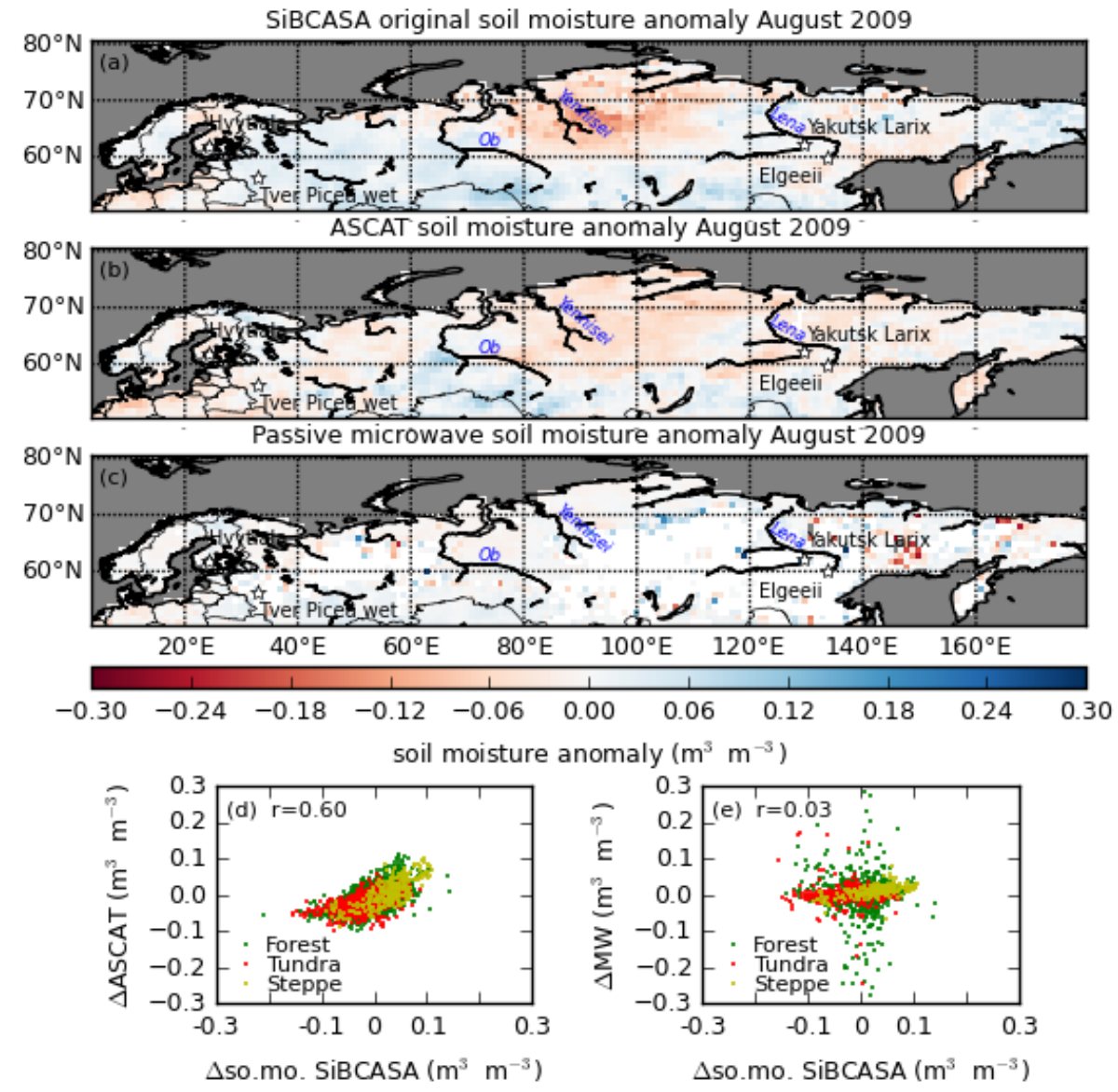

Figure 2. Soil moisture anomalies in August 2009 with respect to the average soil moisture in the months August 2007-2011. (a)-(c) The anomaly in SiBCASA, ASCAT and passive microwave soil moisture. (d) The spatial correlation between the anomalies in ASCAT and SiBCASA soil moisture; each point represents one grid point in the maps (a) and (b). (e) The spatial correlation between passive microwave and SiBCASA soil moisture. The location of the four field sites is shown with open asterisks.

monthly soil moisture anomalies and by quantifying the spatial correlation between the anomalies. We compute the anomalies for each month with respect to the average soil moisture in that month in the years 2007 to 2011. We use the reference period until 2011 (and not 2013), because the AMSR-E satellite became dysfunctional in November 2011, and we have no passive microwave soil moisture after that date. Figure 2 shows an example of the spatial coherence in August 2009. This is the month with the largest spatial correlation between SiBCASA and ASCAT soil moisture in the period that AMSR-E data are available $(r=0.60)$. A dry anomaly in North-central Siberia is apparent in both SiBCASA and ASCAT and a wet anomaly in South and West Siberia, showing that there is coherence in the spatial structure of both data sources. But there are also striking differences. The drought is more intensive and confined to a smaller area in SiBCASA as compared to ASCAT. In addition, east from the Lena River, SiBCASA tends to have a wet anomaly, where ASCAT has a light dry anomaly. Nevertheless, the spatial correlation coefficient is good with $r=0.60$ (second panel in Fig. 2). The correlation appears to be better for wet anomalies than for dry ones. If we compare the soil moisture from the passive microwave data to SiBCASA and ASCAT, no coherent pattern emerges, neither in August 2009 nor in other months. This is reflected in the low spatial correlation coefficient $(r=0.03)$.

These findings are also quite typical for August months in other years. Only in August 2013 was the spatial correlation coefficient between SiBCASA and ASCAT soil moisture slightly larger, $r=0.62$ (figure not shown), but the corresponding AMSR-E data were no longer available. For other months, the spatial patterns are usually less pronounced, and the correlation coefficients smaller. Figure 3 shows the seasonal evolution of the spatial correlation coefficients, also for the land cover types tundra, forest, and steppe (i.e. grasslands and croplands) separately. The correlation coefficients are generally small outside the summer months. Steppe regions have larger correlation coefficients, and tundra regions smaller ones. The overall correlation coefficient is strongly dominated by the forests, because forests cover by far the 
largest part of the study region (66\%), versus $24 \%$ for tundra and $9 \%$ for steppe. In the discussion we will provide potential explanations for the variation of the correlation coefficients over the seasons and over land cover types.

Considering the seasonal evolution of the correlation coefficients between SiBCASA and passive microwave soil moisture, there is no coherence between the two, except perhaps for the steppe regions, for which the correlation coefficients reach to 0.50 in Septembers. However, the slope of the regression curve is only about 1:3 (third panel of Fig. 2), whereas it is near 1:1 for ASCAT soil moisture (second panel of Fig. 2). Because the prior agreement between SiBCASA and passive microwave soil moisture is too low for Boreal Eurasia, we do not consider it meaningful to proceed with assimilation in SiBCASA. We will focus on the ASCAT soil moisture alone in the remainder of this paper. This decision will be further addressed in the discussion section.

The spatial correlation is a measure of how well satellite and SiBCASA agree on the location of drought and wet regions. For assimilation purposes it is also interesting to investigate the temporal correlation at each location. The temporal correlation coefficient is a measure of how well satellite and SiBCASA agree on the timing of dry and wet periods. Figure 4 shows the temporal correlation coefficient between SiBCASA and ASCAT daily soil moisture for all August months between 2007 and 2013 (31 days $\times 7$ days). We discarded all grid points where the associated observational error exceeds $0.25 \mathrm{~m}^{3} \mathrm{~m}^{-3}$ and all locations where time series had less than $50 \%$ coverage. The correlation coefficients are quite large, up to 0.80 in the West Siberian Plains southwest of the $\mathrm{Ob}$ River, with a transition zone via the Yenissei River to the West Siberian tundra region. The Yenissei River marks the western border of the Central Siberian Plateau, where the correlations are much smaller $(0<r<0.2)$. In eastern Siberia, east of the Lena River, the correlations are variable, but generally small and sometimes even negative $(-0.3<r<0.3)$. This pattern is somewhat representative for July, August, and September (see Figs. S1 and S2 in the Supplement, except that in September the area northeast of $60^{\circ} \mathrm{N}, 90^{\circ} \mathrm{E}$ is masked out for the lack of good-quality satellite data. Since we do not calculate correlations when SiBCASA simulates frozen soil or when good-quality data are lacking, an apparent "winter mask" advances from the northeast in September to cover all of the region by December. In April this winter mask regresses into Siberia and disappears in June. As expected, at the front of the winter mask, which is generally $5^{\circ}$ wide, the correlations are low and patchy. We will consider potential underlying reasons for these patterns in the discussion.

The temporal correlations shown in Fig. 4 were computed with soil moisture on a daily basis. When computed on a monthly average basis, the correlation coefficients generally improve considerably, but the variability in soil moisture is smaller accordingly. This shows that day-to-day noise, particularly in the satellite soil moisture data, is responsible for

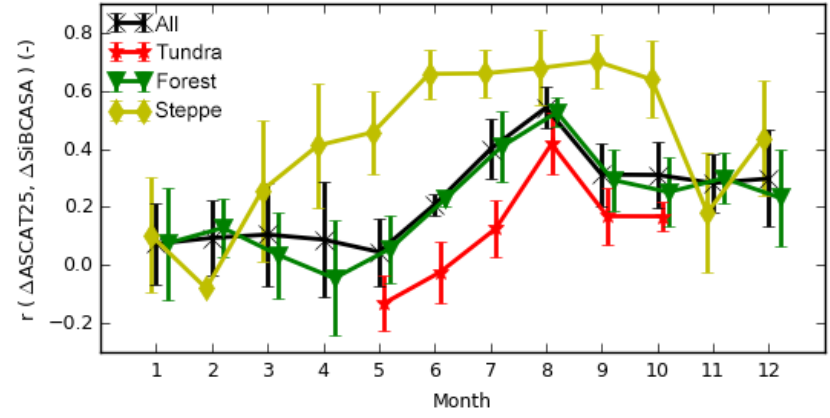

Figure 3. The seasonal variation of the spatial correlation coefficient of SiBCASA and ASCAT soil moisture for all grid cells (black $\mathrm{x}$ ), tundra cells (red *), forest (green triangles), and steppe (brown diamonds). The errorbars indicate the variation between the years 2007-2013.

the low correlation coefficients, and that the remaining correlation is dominated by inter-annual variations. This suggests that it may be worthwhile to investigate assimilation of lowpass filtered satellite soil moisture instead of instantaneous measurements.

To better understand what these large-scale spatial and temporal correlation coefficients imply for the use of satellite soil moisture for assimilation in SiBCASA, time series of soil moisture were compared for four stations across Eurasia. In these time series we show the original SiBCASA soil moisture, the ASCAT soil moisture (CDF-matched), and in situ soil moisture. In addition, we show the SiBCASA soil moisture after assimilation of ASCAT soil moisture according to Sect. 2.3. The first station is Hyytiälä in Finland. The time series are shown in Fig. 5. Simulated and in situ observed soil moisture generally change slowly in time, because of the soil moisture retention in the soil. Since satellite observations lack this memory effect, the satellite observations are noisier. Over the years ASCAT and in situ soil moisture are larger than SiBCASA soil moisture in the spring period (May to early June). This causes the assimilation procedure to increase soil moisture in SiBCASA (red line is higher than the blue line). This increase of soil moisture in the spring period improves the match with in situ observed soil moisture to the degree specified by the uncertainties (Eq. 2).

We loosely define a drought as a period when in situ observed soil moisture is more below the average soil moisture in that period (see bottom panels of Figs. 5-8) than the dayto-day variation during three or more weeks. Subsequently, two distinct drought periods in the time series occurred in July/August 2010 and in July/August 2013. In 2010 the original SiBCASA simulation also "saw" the drought, but ASCAT did not. The assimilation therefore decreased the match with in situ soil moisture. In 2013 the in situ observed drought in Hyytiälä was picked up by neither SiBCASA nor ASCAT.

The second site we analyse is "Tver wet forest", for which the time series are shown in Fig. 6. In Tver, a 


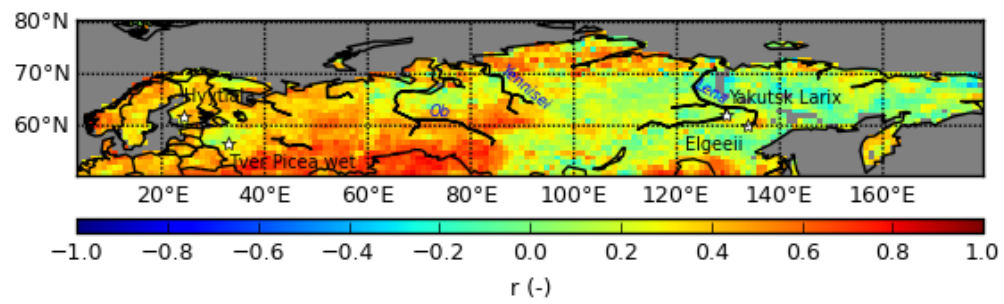

Figure 4. The temporal correlation coefficient of SiBCASA and ASCAT soil moisture for all August months in the period 2007-2013 (7 years $\times 31$ days).

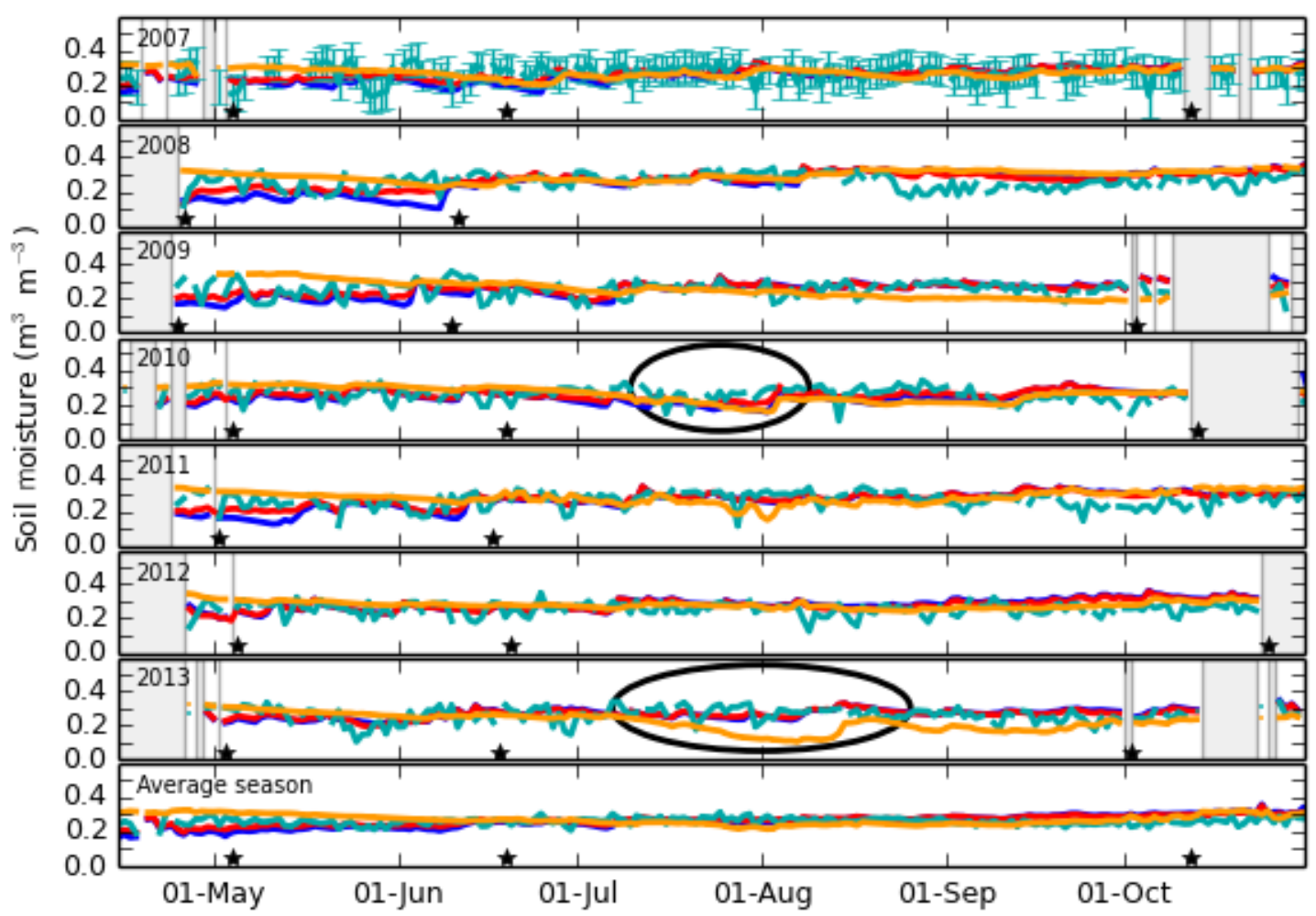

Figure 5. Time series of soil moisture in SiBCASA original (without assimilation) (blue), and with assimilation (red), in situ soil moisture (orange), and ASCAT soil moisture (marine) in Hyytiälä, Finland. Each panel shows 1 year of soil moisture. Grey shades indicate periods when the top soil is frozen. The three asterisks indicate the date when the top soil is last frozen in the spring, 46 days after that, and the date when the top soil is first frozen again in the fall. Error bars in the top panel indicate the uncertainty in ASCAT soil moisture, which is for clarity only shown for 1 year. The bottom panel shows the average seasonal cycle of the each soil moisture type. In situ and ASCAT soil moisture are CDF-matched to SiBCASA soil moisture, which explains why they have the same mean and standard deviation.

similar springtime behaviour emerges. ASCAT is generally larger than SiBCASA soil moisture in April to early May, and the assimilation improves the match with in situ observed soil moisture. Field workers confirm that the water table is generally high or even above the soil surface after snowmelt (April) and decreases quickly in May. In the summers, soil moisture is generally quite constant, except during the 2010 drought, which caused extensive fires in European Russia. The drought was picked up by in situ observations and SiBCASA, but not by ASCAT. As a consequence, the assimilation decreased the match of SiBCASA with in situ soil moisture.

The third site is Yakutsk Larix. At this site, ASCAT soil moisture is noisier than for the other sites (Fig. 7). There is a tendency that in situ soil moisture is high in spring, due to melted snow, and decreasing during the season. This trend is reproduced by SiBCASA in 2007 and 2008 and perhaps in 2009, but not in 2011 to 2013. The ASCAT signal tends to be smaller than average in the spring, and increases somewhat in the summer. There are four intense "droughts" in the in situ time series - in 2008, 2011, 2012, and 2013. Ohta et 


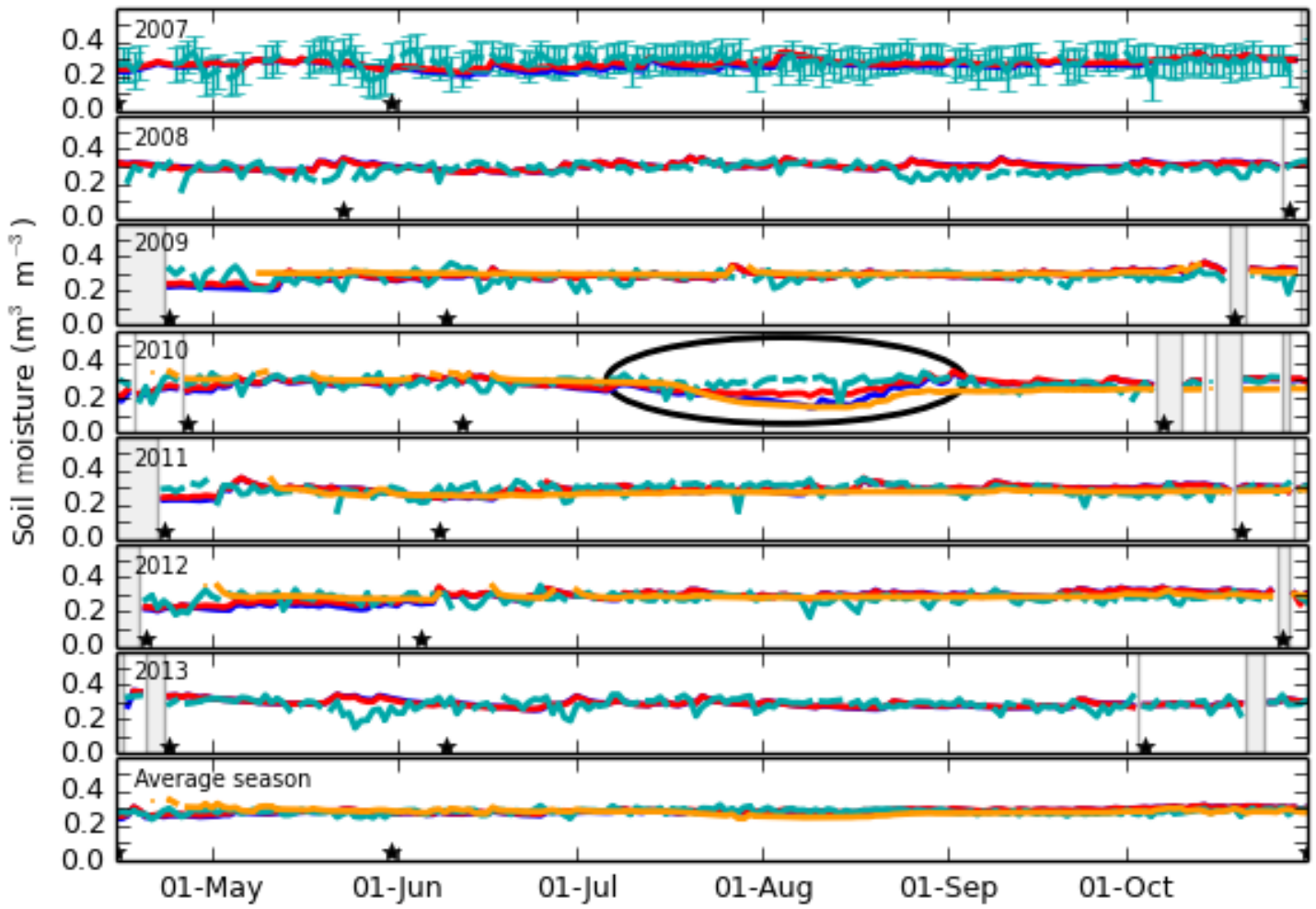

Figure 6. As Fig. 5, but for the Tver wet forest site.

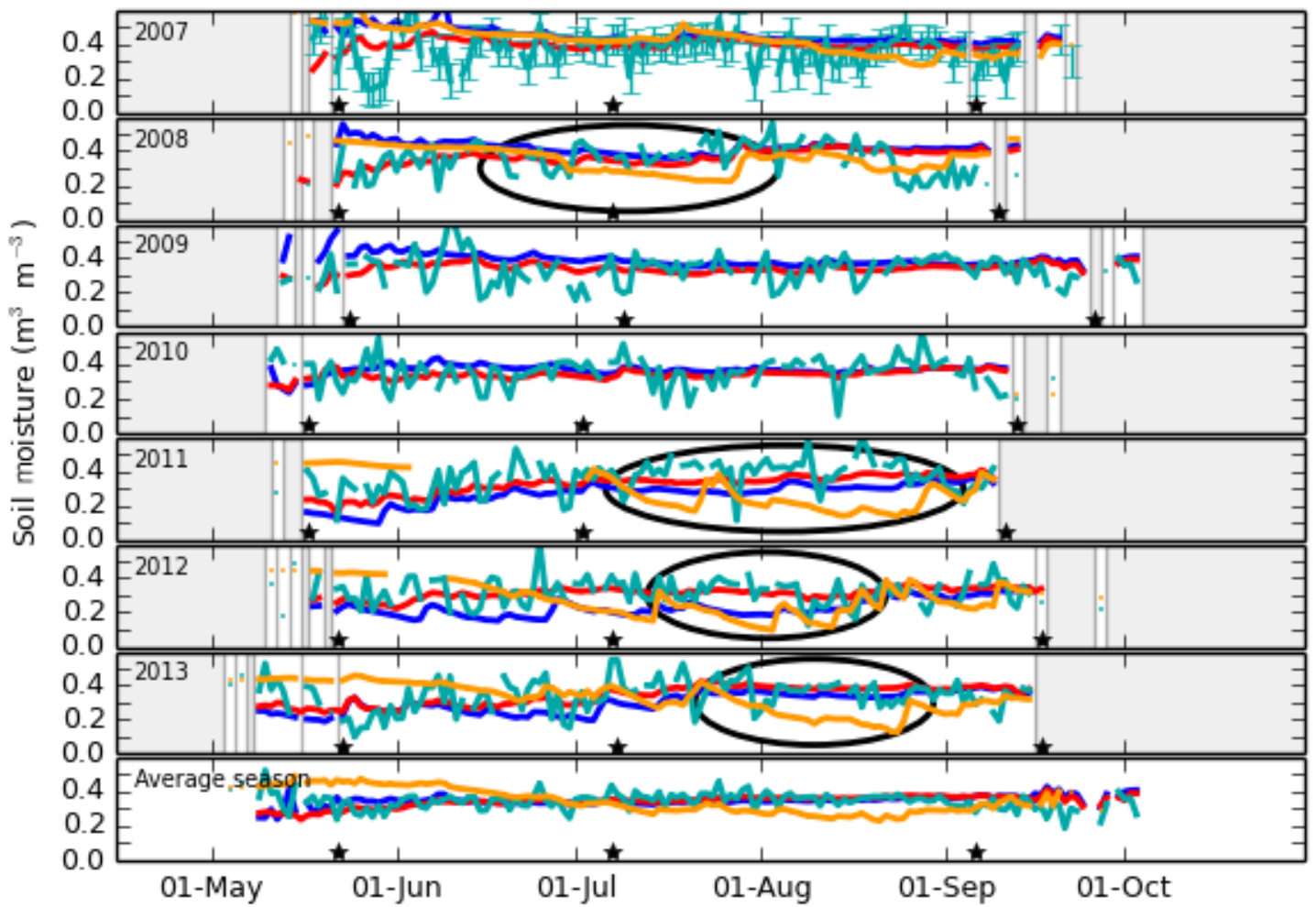

Figure 7. As Fig. 5, but for the Yakutsk Larix site. 


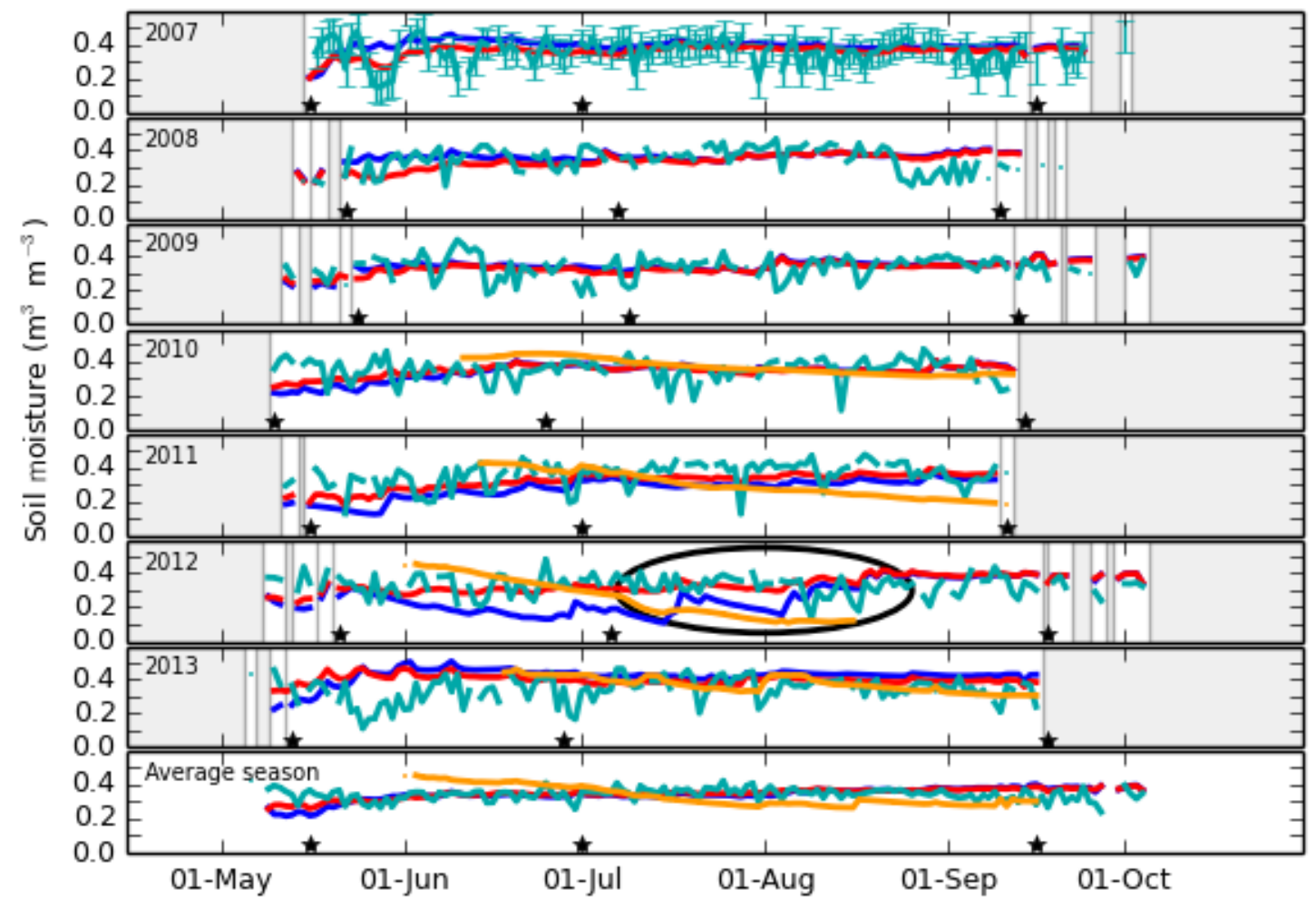

Figure 8. As Fig. 5, but for the Elgeeii site.

al. (2014) show that drought conditions at the site occurred between 2001 and 2004, and that the site was actually water logged from 2005 to 2009 , returning to normal conditions afterwards. The water logging had severe impact on the ecosystem, with reduced photosynthesis rates and tree browning and mortality. This water logging may be a largerscale process in eastern Siberia (Muskett and Romanovsky, 2009; Vey et al., 2013). Therefore the term "drought" is relative to the studied period. SiBCASA sees the in situ observed droughts in 2008 and 2012 to some extent, but not the 2011 and 2013 ones. This inter-annual variation in soil moisture data is reflected in the minimum summertime in situ observed soil moisture in Fig. 7, which is much lower in 2011-2013 than in 2007-2008. ASCAT does not detect this inter-annual variation. ASCAT also does not observe the droughts, whereas the ASCAT soil moisture is generally even larger than in SiBCASA, causing the assimilation to decrease the match with in situ soil moisture.

The fourth site is Elgeeii, for which the time series are shown in Fig. 8. SiBCASA soil moisture is again low in the springtime (May), and ASCAT soil moisture is larger. The assimilation increases the soil moisture in SiBCASA, and this seems to improve the match with in situ observed soil moisture, although the early springtime in situ observations were unreliable. In 2012 a drought occurred in July and August. SiBCASA sees the drought too, although with a much earlier development. ASCAT does not see the drought, and as a consequence, the assimilation moves the soil moisture in SiBCASA away from the in situ observations. It is interesting to see that on 5 August 2012 the soil moisture in SiBCASA increases due to a precipitation event, but this is not seen in the in situ observations. However, an increase is seen at that time in the in situ observations in Yakutsk, some $340 \mathrm{~km}$ to the northeast, possibly suggesting a displacement of the precipitation event in the SiBCASA driver data from ECMWF ERA-interim.

Of the 11 droughts observed in the in situ time series at the four sites, SiBCASA reproduces four, and ASCAT none (Table 2). The poor skills of ASCAT to reproduce local drought conditions are an apparent contradiction given the good skills in positioning the major drought regions shown in Figs. 2 and 3. Particularly at the locations of our in situ observation sites ASCAT does not perform well in reproducing the temporal variability (see Fig. 4), which is confirmed at the site level in Figs. 5-8. To explain this better, we look at monthly mean soil moisture maps for the five drought occurrences which SiBCASA observes, but ASCAT does not.

In August 2010 there was a large drought and heat wave in European Russia and western Siberia, which was caused by a strong blocking situation. The drought was accompanied with many wildfires (Miralles et al., 2014; Krol et al., 2013). The drought was also apparent in the in situ measurements performed in Hyytiälä and Tver. Figure 9 shows that SiBCASA simulates a drought extending from Scandi- 

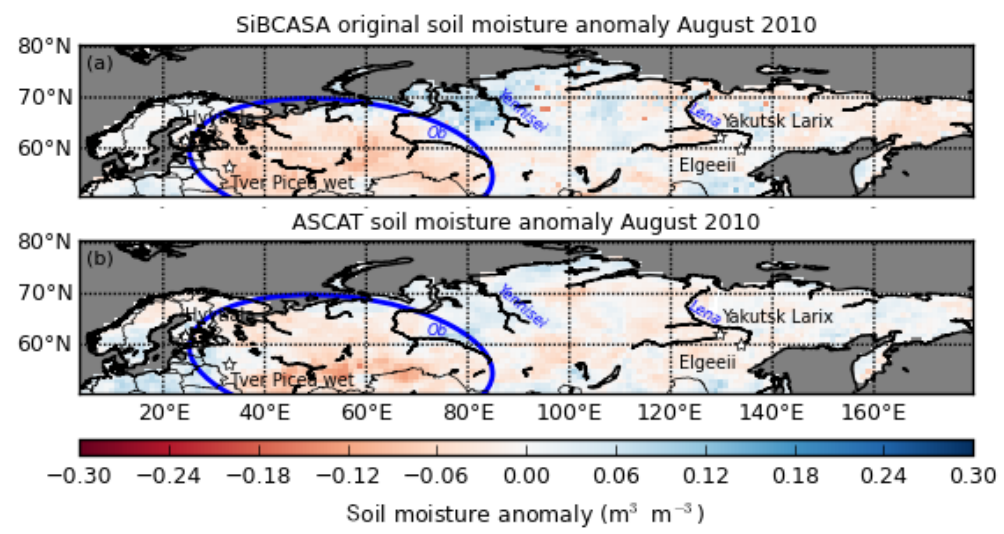

Figure 9. Monthly mean soil moisture in (a) SiBCASA and (b) ASCAT in August 2010. The ellipse shows the extent of the 2010 drought according to SiBCASA.

Table 2. Detection of in situ observed drought occurrences by SiBCASA and ASCAT.

\begin{tabular}{lllccc}
\hline & & & \multicolumn{3}{c}{ Drought seen by } \\
\cline { 4 - 6 } Year & Month & Site & In situ & SiBCASA & ASCAT \\
\hline 2008 & July & Yakutsk & yes & - & no \\
2010 & July/August & Hyytiälä & yes & yes & no \\
2010 & August & Tver & yes & yes & no \\
2011 & July/August & Yakutsk & yes & no & no \\
2012 & July/August & Yakutsk & yes & yes & no \\
2012 & July/August & Elgeeii & yes & yes & no \\
2013 & July/August & Hyytiälä & yes & no & no \\
2013 & July/August & Yakutsk & yes & no & no \\
\hline
\end{tabular}

navia to Novosibirsk $\left(55^{\circ} \mathrm{N}, 80^{\circ} \mathrm{E}\right)$, with the Hyytiälä and Tver sites on the western rim of the drought region. ASCAT locates a drought in roughly the same region, although less intense and with a smaller geographical extent. The ASCAT wet anomaly over Europe expands further into Russia and Scandinavia. As a result, the sites Hyytiälä and Tver are just outside of the drought region as observed by ASCAT and this is most likely attributable to the ASCAT soil moisture retrieval skills. Figure 4 shows that the ASCAT performance is low around those sites. In Sect. 5 (and Fig. 12) we will discuss the performance at the sites in more detail.

In July 2012 SiBCASA simulates an intense drought that was located around the city Yakutsk, extending eastward to the region between the Lena and Aldan rivers (Fig. S3). The Elgeeii site was located just on the eastern border of the simulated drought region. ASCAT does not observe this drought region, not in July, nor in earlier or later months. Where Elgeeii was on the perimeter of the 2012 drought region, as were Hyytiälä and Tver in 2010, Yakutsk was in the centre of the drought region, which ASCAT does not observe at all. Therefore a site's location on the rim of a drought does not explain why ASCAT does not observe the drought. Rather it appears that ASCAT has limited capability to ob- serve droughts in the forested zone where the in situ observations were made.

\subsection{Impact of assimilation of ASCAT soil moisture in SiBCASA on carbon fluxes}

The changes in soil moisture in springtime and during drought, induced by the assimilation of ASCAT observed soil moisture in SiBCASA (Sect. 3.1, Figs. 5-8), may have substantial effects on the representation of the carbon fluxes, which we will look at next. We will show separately how GPP, TER, and NEE depend on the change in soil moisture and the season.

An interesting case is presented at the Yakutsk Larix site (Fig. 10). At this location, the change in soil moisture due to assimilation of ASCAT soil moisture was large relative to the other sites (Fig. 7). However, although the absolute value of the change in soil moisture was more or less constant throughout the years, the change in GPP shows a distinct seasonal cycle, with large changes in spring, small changes in summer, and hardly any change in fall. This is because of two reasons: (i) the sensitivity of GPP to soil moisture is simulated as a function of the plant-available water fraction (Sect. 2.1, Fig. 1a). In Yakutsk in spring, the permafrost soil has only thawed for a couple of centimetres, resulting in a very small plant available water fraction and very strong soil moisture sensitivity (Fig. 1a: the soil moisture sensitivity curve is steepest on the low plant-available water fraction side). This results in a strong GPP effect of assimilating ASCAT soil moisture in SiBCASA. Note that soil thawing does not automatically mean that more soil moisture becomes available for root uptake. The soils in Yakutsk often freeze after a relatively dry summer, so that the frozen soil may be quite dry. In the spring, the snow meltwater cannot penetrate the soil, which is still frozen, and may run off; (ii) the Yakutian spring is almost simultaneous with the solar maximum on 21 June, so that the potential GPP is large. In the course of the growing season, the permafrost active 


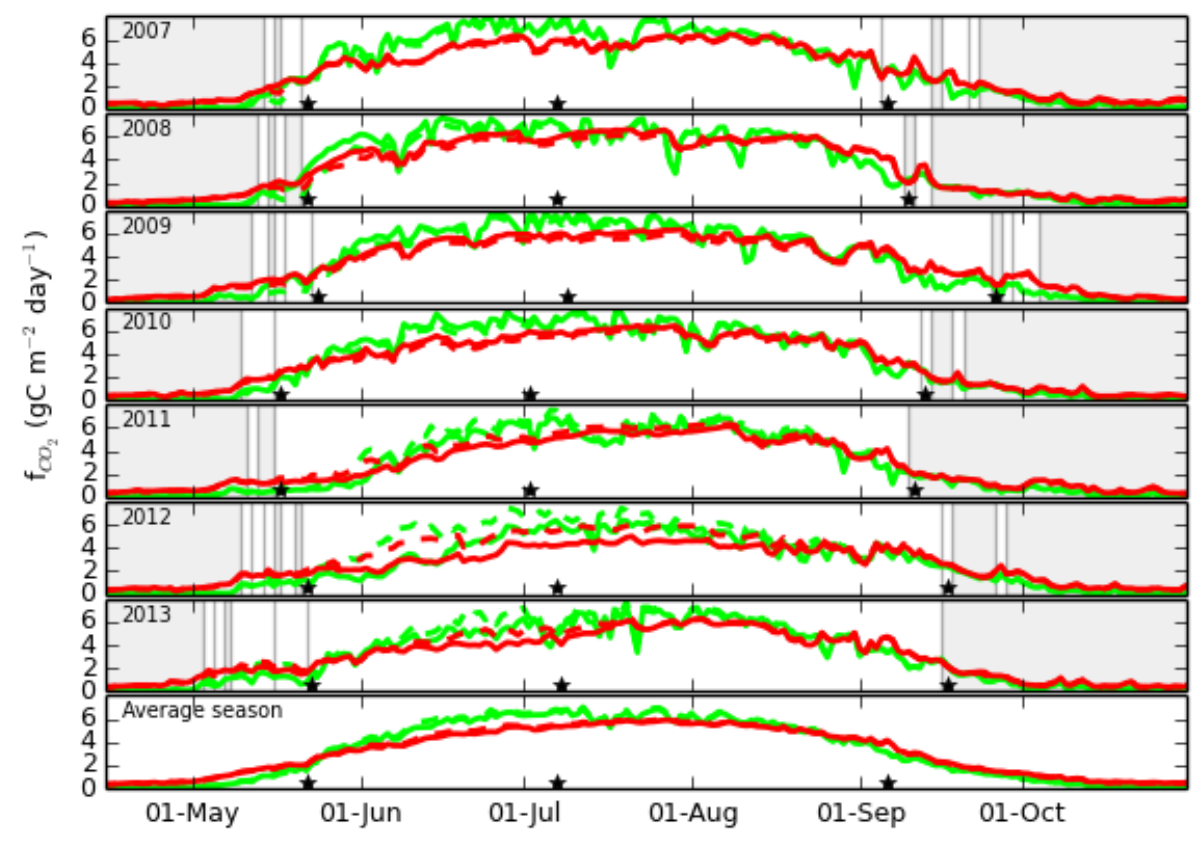

Figure 10. GPP (green) and TER (red) simulated with SiBCASA without (solid lines) and with assimilation (dashed lines) of ASCAT soil moisture for Yakutsk Larix.

layer thaws deeper, resulting in a larger plant-available water fraction, reducing the drought sensitivity. This explains the smaller change in GPP in the summer. In the fall, GPP is limited more by the lack of available sunlight than by water stress, explaining the absence of change in GPP with assimilation of satellite soil moisture data.

In a similar way, the change in TER (Fig. 10) does not only depend on the change in soil moisture with satellite soil moisture assimilation, but also in the absolute value of soil moisture (Fig. 1b) and temperature limitation on TER. In June, when the soil is still cold, the changes in TER are small. In July and August the changes in TER are larger than in GPP, because the soil is warm and TER is a function of absolute soil moisture change. In this example, the changes in GPP and TER have the same direction. Figure 1 shows that this is always the case when the soil moisture saturation fraction is below its minimum value of $\sim 60 \%$. Consequently, the changes in GPP and TER compensate each other partly in the NEE.

Accumulated over a year (Table 3), the changes in GPP, TER, and NEE are of the order of tens of $\mathrm{gC} \mathrm{m}^{-2} \mathrm{yr}^{-1}$, amounting to a few percent of GPP and TER. For NEE however, the changes can amount to tens of percent and a 7-year mean of $-34 \%$. We note that the changes in GPP and TER are larger in Yakutsk than in Hyytiälä, Tver, and Elgeeii. This is because the plant-available water fraction is smaller in Yakutsk than for the other sites, creating a strong drought sensitivity, and because the change in soil moisture is larger. While the relative changes in GPP and TER for these sites is generally small, and they partly compensate, the 7-year mean changes in NEE are $+52 \%$ at Hyytiälä, $-105 \%$ at Tver, and $-38 \%$ at Elgeeii.

The effects of ASCAT soil moisture assimilation in SiBCASA are also significant when integrated over the entire study domain $\left(27.8 \times 10^{6} \mathrm{~km}^{2}\right)$ and the year (Fig. 11). The mean simulated NEE is $-1.91 \mathrm{PgC} \mathrm{yr}^{-1}$ with an interannual variation of $0.12 \mathrm{PgC} \mathrm{yr}^{-1}$ (RMSD). Assimilation of ASCAT soil moisture in SiBCASA causes a change of $0.045 \mathrm{PgC} \mathrm{yr}^{-1}$ (RMSD). This is $41 \%$ of the normal interannual variation of $0.11 \mathrm{PgC} \mathrm{yr}^{-1}$ (RMSD), and $2.4 \%$ of the mean NEE. The effect of satellite soil moisture assimilation is negligible until May; it then grows in the months June and July. After August, the net effect does not change much. This is in line with the observation that the effect of assimilation on soil moisture and carbon fluxes is largest in springtime (Sects. 3.1 and 3.2, Figs. 5-8 and 10). The effect of assimilation was largest in 2010 with an extra anomaly in NEE of $+0.08 \mathrm{PgC} \mathrm{yr}^{-1}$ (less uptake). This anomaly grew between May and September. In this year, a widespread drought occurred in European Russia and West Siberia, which ASCAT captures quite well. The assimilation effect could have been even larger if ASCAT had not wrongfully detected a wet anomaly over far eastern Siberia, where SiBCASA simulates a second drought region (Fig. 9).

The second largest effect of soil moisture assimilation occurred in 2012, with an extra anomaly of $-0.07 \mathrm{PgC} \mathrm{yr}^{-1}$ (more uptake). This anomaly grew mostly in June and July, when ASCAT soil moisture was much higher in June over large parts of Siberia, and the July drought in Central Siberia was confined to a smaller region in ASCAT data. 
Table 3. GPP, TER, and NEE in SiBCASA without ASCAT soil moisture assimilation, and the changes dGPP, dTER, dNEE with assimilation for the site Yakutsk Larix.

\begin{tabular}{|c|c|c|c|c|c|c|c|c|c|}
\hline & \multirow{2}{*}{$\begin{array}{c}\text { GPP } \\
\mathrm{gC} \mathrm{m}^{-2} \mathrm{yr}^{-1}\end{array}$} & \multicolumn{2}{|l|}{ dGPP } & \multirow{2}{*}{$\begin{array}{c}\text { TER } \\
\mathrm{gC} \mathrm{m}^{-2} \mathrm{yr}^{-1}\end{array}$} & \multicolumn{2}{|l|}{ dTER } & \multirow{2}{*}{$\begin{array}{c}\text { NEE } \\
\mathrm{gC} \mathrm{m}^{-2} \mathrm{yr}^{-1}\end{array}$} & \multicolumn{2}{|l|}{ dNEE } \\
\hline & & $\mathrm{gCm}^{-2} \mathrm{yr}^{-1}$ & $\%$ & & $\mathrm{gC} \mathrm{m}^{-2} \mathrm{yr}^{-1}$ & $\%$ & & $\mathrm{gCm}^{-2} \mathrm{yr}^{-1}$ & $\%$ \\
\hline 2007 & 719 & -24 & -3 & 725 & -25 & -3 & 6 & -1 & -22 \\
\hline 2008 & 697 & -45 & -6 & 727 & -45 & -6 & 30 & 0 & 0 \\
\hline 2009 & 710 & -39 & -6 & 733 & -44 & -6 & 23 & -4 & -19 \\
\hline 2010 & 688 & -20 & -3 & 695 & -28 & -4 & 7 & -9 & -123 \\
\hline 2011 & 556 & 53 & 10 & 601 & 41 & 7 & 45 & -12 & -27 \\
\hline 2012 & 524 & 121 & 23 & 553 & 110 & 20 & 28 & -11 & -38 \\
\hline 2013 & 612 & 54 & 9 & 642 & 33 & 5 & 30 & -21 & -68 \\
\hline Mean & 644 & 14 & 2 & 668 & 6 & 1 & 24 & -8 & -34 \\
\hline
\end{tabular}

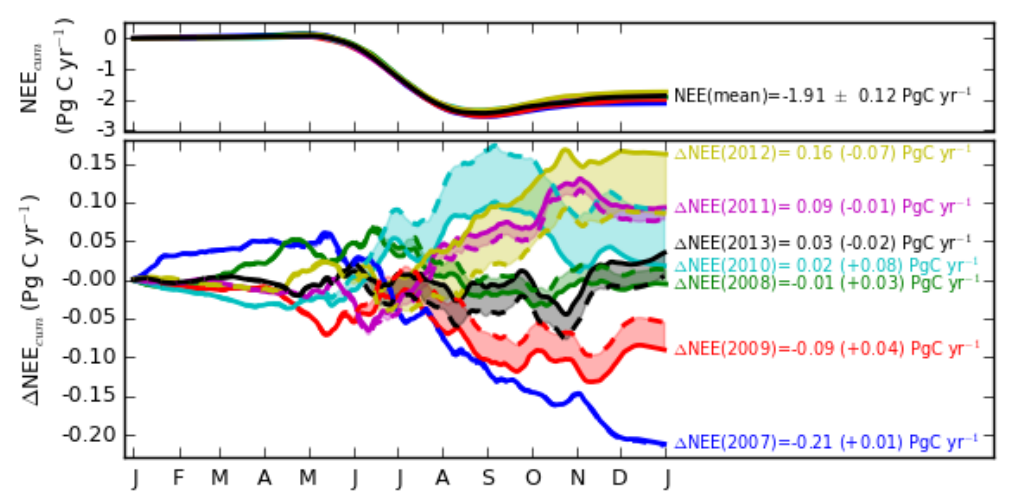

Figure 11. Top panel: cumulative NEE in Boreal Eurasia for the years 2007 to 2013 according to SiBCASA without assimilation of satelliteobserved soil moisture. The text describes the 7-year mean NEE and the inter-annual variation (as standard deviation). Bottom panel: cumulative NEE anomaly relative to the 7-year mean. Solid lines represent the SiBCASA NEE anomaly ( $\triangle$ NEE) without assimilation of ASCAT soil moisture, dashed lines represent the NEE anomaly with assimilation of ASCAT soil moisture. The text behind the lines describes the NEE anomaly relative to the inter-annual mean NEE and in parentheses the change caused by assimilation of ASCAT soil moisture.

\section{Discussion}

\subsection{Soil moisture}

The spatial and temporal correlation coefficients between SiBCASA and satellite-observed soil moisture shown in Sect. 3 suggest that ASCAT and passive microwave satellite signals have a certain skill in observing land surface soil moisture. The absence of perfect correlations implies that assimilating the satellite-observed soil moisture in SiBCASA will have an effect. The question is whether that effect is an improvement.

The performance of passive microwave data was low over the entire study region and in all months (Fig. 2, Sect. 3.1). Only in steppe regions were the temporal correlations large $(r=0.8)$. The spatial correlation is smaller than that $(r \sim 0.5)$ and with a smaller sensitivity (a slope of $\sim 1: 3$, Fig. 2 ), probably because of the absence of significant spatial patterns in the small extent of the steppe zone. The poor performance of the microwave soil moisture in Boreal Eurasia is not entirely surprising: the passive microwave radiation emitted by the soil moisture is known to be disturbed by vegetation, surface water, snow, and ice (de Jeu et al., 2008; Mladenova et al., 2014; Champagne et al., 2010), which are abundant in Boreal Eurasia. The microwave soil moisture product has been validated extensively (Miralles, 2011; Miralles et al., 2011b; de Jeu et al., 2008; Liu et al., 2011, 2012; Owe et al., 2008; Griesfeller et al., 2016; Champagne et al., 2010). However, the vast majority of the validation sites were located on grasslands and croplands, and in temperate and (semi)arid climate zones. Therefore, the poor performance of microwave soil moisture in Boreal Eurasia, except perhaps the steppe zone, is probably related to the canopy, which is too dense, as well as to the presence of snow, ice, and surface water. Our results are therefore specific to our region, and cannot be simply extrapolated to other climate zones and land covers.

The spatial and temporal correlation coefficients vary with the months and with land cover. The spatial correlation between SiBCASA and ASCAT soil moisture is largest in August and quickly decreases towards the spring and fall. What processes may cause this? Ecologically there are large differ- 
ences between the seasons in Siberia. Large parts of Siberia are snow covered and particularly the region north of Mongolia and east of the Yenissei River is subject to continuous permafrost. This hampers a correct retrieval of soil moisture from satellite-observed signals (Naeimi et al., 2012a; Högström et al., 2014), while correctly simulating soil moisture under snow conditions is also difficult in vegetation models. However, even in the northern tundra regions most snow and ice have disappeared by June. Considering that the grid cells with frozen top soil in SiBCASA and snow/ice detection in ASCAT have been excluded from the statistical analysis, the lower correlations in June, July, and September (Fig. 3) are probably not only caused by the presence of snow and ice on the land surface.

Other important changes from May to July are the expansion of leafs, the drying out of the topsoil after snowmelt on frozen ground, and the deeper thawing of the permafrost active layer. The increase of the leaf area index (LAI) does not seem beneficial for better satellite soil moisture retrievals, as is also suggest by the smaller correlation coefficients for forests than for steppe zone (Fig. 3). The decrease in the ponded area fraction after snowmelt on frozen ground is a potential explanation for the improving correlation coefficients (Högström et al., 2014), since they occur particularly in the forest and the tundra zones, which contain the wettest parts of the region, and not for the steppe zone, which is drier and outside the permafrost zone.

With the same arguments the increasing depth of the permafrost ice front may also be a potential explanation of the improving spatial correlation coefficients towards August. Indeed, ice and frozen soil at some depth may disturb the satellite signal (Way et al., 1997; Wegmüller, 1990). Maximum active layer thicknesses of a mere $10-20 \mathrm{~cm}$ are not uncommon in the northern tundra, although the penetration depth of microwave radiation in the soil is of the order of one to a few centimetres.

It is interesting that the spatial correlation coefficients for steppe zones are larger and for tundra zones smaller than average. Both steppe and tundra vegetation are characterized by short vegetation, but tundra regions are generally much wetter than steppe regions and with continuous permafrost. This implies that the presence of short vegetation alone is not the only prerequisite to obtain a good match between SiBCASA and ASCAT soil moisture.

On the site level, Figs. 5-8 show that ASCAT soil moisture has much more day-to-day variability than SiBCASA soil moisture. While SiBCASA soil moisture has a significant, physically meaningful auto-correlation with lag times up to 10-17 days $(r>0.3)$, ASCAT observations and associated errors are independent in time, which indicates that the signal is compromised by measurement noise. On top of this, ASCAT was not able to detect the eight large drought occurrences observed in situ soil moisture time series, nor the pronounced inter-annual variation associated with recovery after water logging in Yakutsk. This is reflected in small site-level temporal correlation coefficients between in situ soil moisture and ASCAT soil moisture $(r<0.06$ at all sites), while the June-September correlation between in situ soil moisture and SiBCASA soil moisture is much larger ( 0.49 at Hyytiälä, 0.63 at Tver, 0.74 at Yakutsk and 0.76 at Elgeeii). The applicability of in situ soil moisture observations for this purpose is supported by Robock et al. (2000) and Mittelbach and Seneviratne (2012). This suggests that SiBCASA soil moisture is more reliable than ASCAT soil moisture at these sites. This is not entirely surprising, because Fig. 4 shows that the in situ observations were made at locations outside the area of high temporal correlations between SiBCASA and ASCAT. However, it suggests that the low correlations outside the steppe zone are more likely to be due to poor performance of ASCAT soil moisture than to SiBCASA soil moisture. It is unfortunate that there were no in situ observations during the ASCAT period of operation to evaluate ASCAT observations in the core drought regions. Now the added-value of ASCAT observations remains limited, because of the remaining questions about their accuracy.

On the positive side, in Figs. 5-8 we found a quite consistent pattern in springtime, which indicates that ASCAT soil moisture was larger than SiBCASA soil moisture, and assimilation seemed to improve the match with in situ observed soil moisture. Is this a realistic pattern? Experimentalists confirm that ponding after snowmelt occurs on the sites. However, it is known that ASCAT soil moisture is unreliable when the footprint of the observation is (partially) covered with snow, ice, or surface water, which is likely to happen in springtime. At the same time, SiBCASA soil moisture in spring depends on the amount of snow accumulated in the winter, the time of snowmelt, the fate of the meltwater on frozen ground (runoff or ponding). Since it is hard to simulate these processes correctly, also considering the coarse resolution of SiBCASA relative to dependency of these processes on topography, springtime soil moisture in SiBCASA may also be questioned. Nevertheless, this springtime underestimation pattern is also observed at other steppe and forest grid cells where the temporal correlations are large. Thus there are indications that the spring wetting with assimilation of ASCAT data in SiBCASA improves the soil moisture. Field workers (see author contributions) confirm the springtime water logging and ponding at the four sites. High water tables during springtime are followed by drying out of the soil, depending on the weather conditions. The low soil moisture in SiBCASA could be caused by overestimation of the evapo-transpiration rates in the spring.

In an attempt to explain the variation in temporal correlation coefficients over the region, Fig. 12 shows the temporal correlation coefficient of SiBCASA and ASCAT soil moisture in August 2013 as a function of several variables. Each dot in the figures represents a grid point. With increasing LAI the correlation coefficient $r$ indeed decreases, which is physically logical, because water in leafs disturbs the soil moisture signal. Similarly, the aboveground carbon 

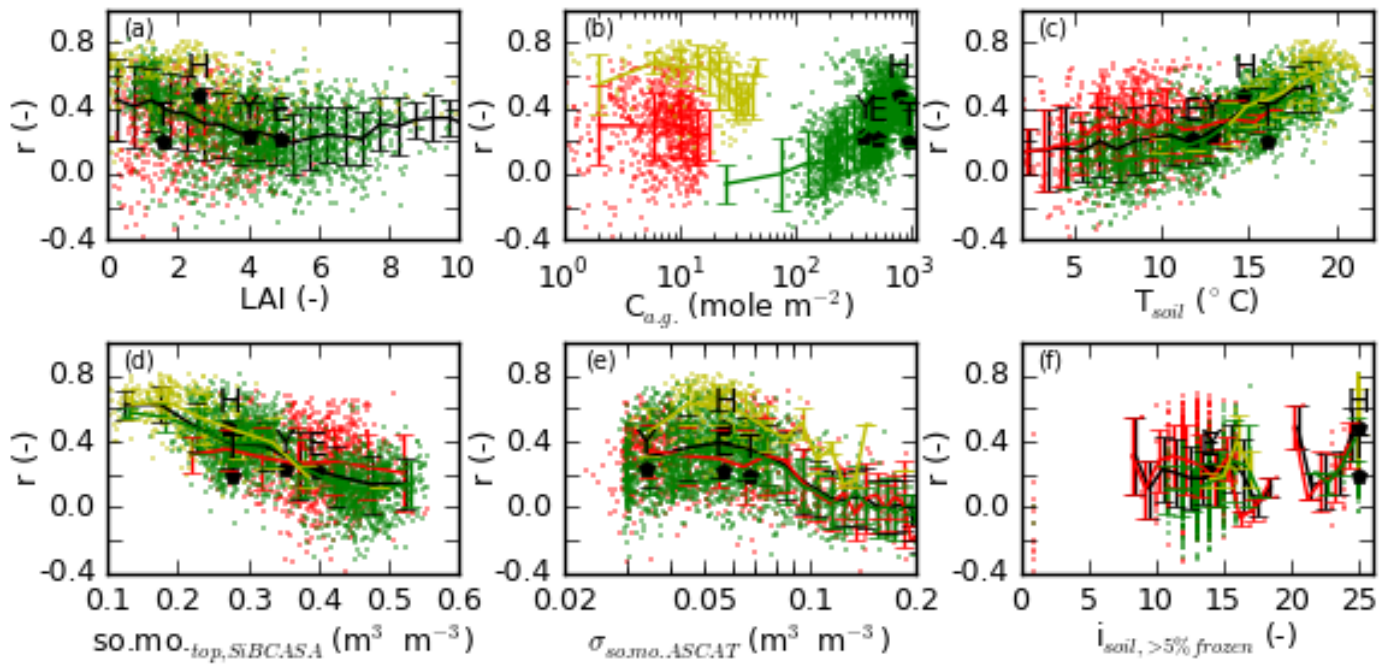

Figure 12. Variables possibly explaining the temporal correlation coefficient of SiBCASA and ASCAT soil moisture: (a) leaf area index; (b) aboveground carbon; (c) soil temperature; (d) top soil moisture in SiBCASA; (e) the uncertainty in ASCAT soil moisture; (f) the first soil layer with frozen fraction larger than $5 \%$. Red colours represent tundra pixels, green ones forest pixels, and yellow dots steppe pixels. The $r$ represents the correlation coefficient between SiBCASA and ASCAT in all August days in the period of record ( 31 days $\times 7$ years). The four black marks indicate the characteristics of the four sites Hyytiälä (H), Tver (T), Yakutsk (Y) and Elgeeii (E).

in biomass has a negative relationship with $r$ for steppe, but not for forests and tundra zones. For forests, the relationship is, counterintuitively, positive. This may be explained by a cross-correlation between carbon in biomass and temperature: the forest biomass decreases towards the northern treeline, where temperatures are lower. Apparently, aboveground biomass itself does not necessarily disturb the satellite signal. Soil temperature has a positive relation with $r$, and there is no indication that the relationship saturates at higher temperatures. This is a somewhat puzzling observation. We would have expected low correlation coefficients at low temperatures, due to the presence of snow and ice, but at temperatures higher than $10^{\circ} \mathrm{C}$ the ice would have disappeared, and we would not have expected an increase in $r$ with temperature. Possibly, higher temperatures are indicative of a longer period into the local growing season, when soil ponding has diminished after snowmelt and the performance of SiBCASA is consequently better. This is confirmed by the negative relation between top soil moisture in $\mathrm{SiB}$ CASA with $r$. At large soil moisture contents, the chance of (partial) ponding is larger, with subsequent disturbances of the satellite signal (see Naeimi et al., 2012b; Högström et al., 2014; but also Griesfeller et al., 2016). The correlation coefficients between SiBCASA and ASCAT are best when the error estimate of the retrieved ASCAT soil moisture is smaller than $10^{-1} \mathrm{~m}^{3} \mathrm{~m}^{-3}$. Finally, the top most soil layer which contains ice is a poor predictor of $r$. Where the first layer is frozen, the $r$ are indeed near 0 , but all other grid points have ice only much deeper than the eighth soil layer, and there is no relation with $r$. This essentially means that permafrost does not disturb the satellite signal in August in
Siberia. The characteristics of the four field sites are indicated by black marks in Fig. 12. This shows that the performance at the Yakutsk and Elgeeii sites may be expected to be low, because of the large LAI, low temperatures, and relatively large soil moisture. At the Tver and Hyytiälä sites, the expected performance is better, although the Tver site performs below average. We can only guess what might explain this difference. The region around the Tver site is quite heterogeneous, with a mixture of Spruce and deciduous forests and peat bogs, rivers and Lake Seliger. Perhaps the LAI is in reality larger than SiBCASA predicts, and the satellite retrieval is hampered by surface water.

In conclusion, (partial) ponding of the soil appears to be a good potential explanation of why the poor performance of ASCAT soil moisture improves into the summer months in Boreal Eurasia. The presence of dense leafs rather than aboveground biomass disturbs the satellite signal.

\subsection{Carbon effects}

It has been shown in Sect. 3.2 that assimilation of ASCAT soil moisture in SiBCASA has an effect of 5 to $10 \%$ on GPP and TER, and of a few tens of percent on NEE, at the site of Yakutsk, over the entire year. This represents the higher end of the range, since the effect of assimilation on soil moisture and carbon fluxes was relatively large in Yakutsk. The reason why Yakutsk is so sensitive is because the plant-available water fraction is small there, so that the drought sensitivity is large (Fig. 1a). Integrated over the entire region, assimilation causes changes in the order of half the inter-annual variability, or $2 \%$ of the mean annual NEE. We consider this 
quite large, given the fact that we only applied the assimilation to the top soil moisture. However, the temporal correlation coefficients were quite low in large parts of the region (Fig. 4). This implies that simulated and observed soil moisture are quite different. Assimilation will thus have a large effect when the observational errors are small. A comparison between observed and simulated NEE is made and discussed in the Supplement (Fig. S4).

The effect of changing soil moisture on GPP is largest in SiBCASA when the plant-available water fraction is smaller than 0.3. The area where this occurs is confined to the steppe zone in Southwest Siberia in South European Russia, where it is dry and in the northeast Siberian forest zone, where water availability is limited by permafrost. If the drought stress function in Fig. 1a were to be defined more linearly, the effects of soil moisture would be spread more evenly over the study domain. Note that it may not be realistic to prescribe identical water stress formulations for all biome types, as SiBCASA does. Furthermore, Fig. 10 shows that the drought sensitivity in Fig. 1 only represents the potential drought sensitivity. The actual sensitivity of GPP to change in soil moisture also depends on the temperature, radiation, and vapour pressure deficit (Fig. 10). This applies to TER in a similar way too. As a result, changes in NEE are not linearly dependent on the change in soil moisture due to assimilation of satellite observed soil moisture. Consequently, local effects may be much larger than $2 \%$ of the mean annual NEE. Furthermore, Ohta et al. (2014) show that, in reality, water logging at high plant-available water fractions may also reduce photosynthesis rates and affect the water use efficiency.

\section{Conclusions}

The spatial and temporal correlation between SiBCASA and ASCAT soil moisture are considerable in the summer period and the steppe zone. However, ASCAT-derived soil moisture fails to detect the eight major droughts observed in situ at four sites during 7 years, while SiBCASA reproduces half of those droughts. At site level, temporal correlations between SiBCASA and in situ observed soil moisture are larger than between SiBCASA and ASCAT soil moisture. These facts suggest that SiBCASA soil moisture is more reliable than ASCAT soil moisture at those four locations and that assimilation of ASCAT soil moisture does not improve SiBCASA soil moisture.

The temporal correlation between SiBCASA and ASCAT soil moisture is best in the steppe zone, and in a selection of forest locations where LAI is low, soil temperature is high, and soil moisture is low (Fig. 12). Unfortunately, we do not have ground observations to prove whether assimilation in such conditions would lead to improved soil moisture in SiBCASA.

There is evidence that assimilation of ASCAT soil moisture improves the match of SiBCASA soil moisture with in situ observations in springtime (Figs. 5-8). However, these results should be taken carefully, because ice and ponding occur often in the spring. Irrespective of the question of whether assimilation improves soil moisture in SiBCASA, assimilation of ASCAT soil moisture causes considerable changes in GPP, TER, and NEE. At individual locations these changes may reach up to 5 to $10 \%$ of annual GPP and TER, and tens of percent of annual NEE, and integrated over the entire region, the changes cause changes of the order of half the interannual variability in NEE or $2 \%$ of annual NEE.

Ultimately, this study shows that assimilation of satelliteobserved soil moisture in vegetation models potentially has large impacts on the simulated carbon fluxes, but that further research is needed to clarify when, where, and in which conditions assimilation leads to more reliable soil moisture simulations. In the near future, important improvements in the quality and spatial resolution of soil moisture are expected to be realized with the SMAP L-band instrument and Sentinel1. Additionally, the benefit of more advanced assimilation techniques, e.g. by assimilating low-pass filtered satellite signals, may be investigated.

\section{The Supplement related to this article is available online at doi:10.5194/hess-20-605-2016-supplement.}

Author contributions. M. K. van der Molen implemented the assimilation scheme and performed the model runs and analysis together with I. R. van der Velde. R. A. M. de Jeu and W. Wagner contributed by discussing the reliability of the satellite-observed soil moisture data. W. Peters and M. C. Krol contributed by discussing the research plan and results. The in situ soil moisture observations were collected and provided by P. Kolari (Hyytiälä), J. Kurbatova, A. Varlagin (Tver), T. C. Maximov, A. V. Kononov, T. Ohta, A. Kotani (Yakutsk and Elgeeii), who also contributed by discussing the reliability of the in situ observations.

Acknowledgements. The research on which this publication is based has been partly funded by the Dutch Organization for Scientific Research (NWO) under grant number 864.08.012 (VIDI WP "A multiple constraint data assimilation system for the carbon cycle"). J. Kurbatova and A. Varlagin, and the in situ observations in Tver were funded by the Russian Science Foundation, Grant 14-27-00065.

Edited by: P. Saco 


\section{References}

Baldocchi, D., Falge, E., Gu, L. H., Olson, R., Hollinger, D., Running, S., Anthoni, P., Bernhofer, C., Davis, K., Evans, R., Fuentes, J., Goldstein, A., Katul, G., Law, B., Lee, X. H., Malhi, Y., Meyers, T., Munger, W., Oechel, W., U, K. T. P., Pilegaard, K., Schmid, H. P., Valentini, R., Verma, S., Vesala, T., Wilson, K., and Wofsy, S.: FLUXNET: A new tool to study the temporal and spatial variability of ecosystem-scale carbon dioxide, water vapor, and energy flux densities, B. Am. Meteorol. Soc., 82, 2415-2434, 2001.

Bartalis, Z., Wagner, W., Naeimi, V., Hasenauer, S., Scipal, K., Bonekamp, H., Figa, J., and Anderson, C.: Initial soil moisture retrievals from the METOP-A Advanced Scatterometer (ASCAT), Geophys. Res. Lett., 34, L20401, doi:10.1029/2007g1031088, 2007.

Champagne, C., Berg, A., Belanger, J., McNairn, H., and De Jeu, R.: Evaluation of soil moisture derived from passive microwave remote sensing over agricultural sites in Canada using groundbased soil moisture monitoring networks, Int. J. Remote Sens., 31, 3669-3690, doi:10.1080/01431161.2010.483485, 2010.

Chen, Y., Yang, K., Qin, J., Zhao, L., Tang, W., and Han, M.: Evaluation of AMSR-E retrievals and GLDAS simulations against observations of a soil moisture network on the central Tibetan Plateau, J. Geophys. Res.-Atmos., 118, 4466-4475, doi:10.1002/jgrd.50301, 2013.

Ciais, P., Reichstein, M., Viovy, N., Granier, A., Ogee, J., Allard, V., Aubinet, M., Buchmann, N., Bernhofer, C., Carrara, A., Chevallier, F., De Noblet, N., Friend, A. D., Friedlingstein, P., Grunwald, T., Heinesch, B., Keronen, P., Knohl, A., Krinner, G., Loustau, D., Manca, G., Matteucci, G., Miglietta, F., Ourcival, J. M., Papale, D., Pilegaard, K., Rambal, S., Seufert, G., Soussana, J. F., Sanz, M. J., Schulze, E. D., Vesala, T., and Valentini, R.: Europe-wide reduction in primary productivity caused by the heat and drought in 2003, Nature, 437, 529-533, doi:10.1038/nature03972, 2005.

Collatz, G. J., Ball, J. T., Grivet, C., and Berry, J. A.: Physiological and environmental regulation of stomatal conductance, photosynthesis and transpiration: a model that includes a laminar boundary layer, Agr. Forest Meteorol., 54, 107-136, 1991.

Dai, A.: Drought under global warming: A review, Wiley Interdisciplinary Reviews: Climate Change, 2, 45-65, doi:10.1002/wcc.81, 2011.

De Jeu, R. A. M. and Owe, M.: Further validation of a new methodology for surface moisture and vegetation optical depth retrieval, Int. J. Remote Sens., 24, 4559-4578, doi:10.1080/0143116031000095934, 2003.

de Jeu, R. A. M., Wagner, W., Holmes, T., Dolman, A., van de Giesen, N., and Friesen, J.: Global Soil Moisture Patterns Observed by Space Borne Microwave Radiometers and Scatterometers, Surv. Geophys., 29, 399-420, doi:10.1007/s10712-0089044-0, 2008.

De Jeu, R. A. M., Holmes, T. R. H., Panciera, R., and Walker, J. P.: Parameterization of the land parameter retrieval model for L-band observations using the NAFE'05 data set, IEEE Geosci. Remote Sens. Lett., 6, 630-634, doi:10.1109/lgrs.2009.2019607, 2009.

de Wit, A. J. W. and van Diepen, C. A.: Crop model data assimilation with the Ensemble Kalman filter for improving re- gional crop yield forecasts, Agr. Forest Meteorol., 146, 38-56, doi:10.1016/j.agrformet.2007.05.004, 2007.

Dolman, A. J., Maximov, T. C., Moors, E. J., Maximov, A. P., Elbers, J. A., Kononov, A. V., Waterloo, M. J., and van der Molen, M. K.: Net ecosystem exchange of carbon dioxide and water of far eastern Siberian Larch (Larix cajanderii) on permafrost, Biogeosciences, 1, 133-146, doi:10.5194/bg-1-133-2004, 2004.

Dolman, A. J., Shvidenko, A., Schepaschenko, D., Ciais, P., Tchebakova, N., Chen, T., van der Molen, M. K., Belelli Marchesini, L., Maximov, T. C., Maksyutov, S., and Schulze, E.-D.: An estimate of the terrestrial carbon budget of Russia using inventory-based, eddy covariance and inversion methods, Biogeosciences, 9, 5323-5340, doi:10.5194/bg-9-5323-2012, 2012.

Draper, C. S., Mahfouf, J. F., and Walker, J. P.: An EKF assimilation of AMSR-E soil moisture into the ISBA land surface scheme, J. Geophys. Res.-Atmos., 114, D20104, doi:10.1029/2008jd011650, 2009a.

Draper, C. S., Walker, J. P., Steinle, P. J., de Jeu, R. A. M., and Holmes, T. R. H.: An evaluation of AMSR-E derived soil moisture over Australia, Remote Sens. Environ., 113, 703-710, doi:10.1016/j.rse.2008.11.011, 2009b.

Entekhabi, D., Njoku, E. G., O’Neill, P. E., Kellogg, K. H., Crow, W. T., Edelstein, W. N., Entin, J. K., Goodman, S. D., Jackson, T. J., Johnson, J., Kimball, J., Piepmeier, J. R., Koster, R. D., Martin, N., McDonald, K. C., Moghaddam, M., Moran, S., Reichle, R., Shi, J. C., Spencer, M. W., Thurman, S. W., Tsang, L., and Van Zyl, J.: The soil moisture active passive (SMAP) mission, Proc. IEEE, 98, 704-716, doi:10.1109/jproc.2010.2043918, 2010.

Farquhar, G. D. von Caemmerer, S., and Berry, J. A.: A biochemical model of photosynthetic $\mathrm{CO}_{2}$ assimilation in leaves of C3 species, Planta, 149, 78-90, doi:10.1007/bf00386231, 1980.

Goetz, S. J., MacK, M. C., Gurney, K. R., Randerson, J. T., and Houghton, R. A.: Ecosystem responses to recent climate change and fire disturbance at northern high latitudes: Observations and model results contrasting northern Eurasia and North America, Environ. Res. Lett., 2, 045031, doi:10.1088/17489326/2/4/045031, 2007.

Griesfeller, A., Lahoz, W. A., d. Jeu, R. A. M., Dorigo, W., Haugen, L. E., Svendby, T. M., and Wagner, W.: Evaluation of satellite soil moisture products over Norway using ground-based observations, Int. J. Appl. Earth Obs. Geoinf., 45, 155-164, doi:10.1016/j.jag.2015.04.016, 2016

Han, E., Crow, W. T., Holmes, T., and Bolten, J.: Benchmarking a soil moisture data assimilation system for agricultural drought monitoring, J. Hydrometeorol., 15, 1117-1134, doi:10.1175/jhm-d-13-0125.1, 2014.

Högström, E., Trofaier, A., Gouttevin, I., and Bartsch, A.: Assessing Seasonal Backscatter Variations with Respect to Uncertainties in Soil Moisture Retrieval in Siberian Tundra Regions, Remote Sensing, 6, 8718-8738, 2014.

Ilvesniemi, H., Pumpanen, J., Duursma, R., Hari, P., Keronen, P., Kolari, P., Kulmala, M., Mammarella, I., Nikinmaa, E., Rannik, Ü., Pohja, T., Siivola, E., and Vesala, T.: Water balance of a boreal scots pine forest, Boreal Environ. Res., 15, 375-396, 2010.

Imaoka, K., Kachi, M., Fujii, H., Murakami, H., Hori, M., Ono, A., Igarashi, T., Nakagawa, K., Oki, T., Honda, Y., and Shimoda, H.: Global change observation mission (GCOM) for monitoring 
carbon, water cycles, and climate change, Proc, IEEE, 98, 717734, doi:10.1109/jproc.2009.2036869, 2010.

Jafarov, E. and Schaefer, K.: The importance of a surface organic layer in simulating permafrost thermal and carbon dynamics, The Cryosphere Discuss., 9, 3137-3163, doi:10.5194/tcd-93137-2015, 2015.

Katul, G., Manzoni, S., Palmroth, S., and Oren, R.: A stomatal optimization theory to describe the effects of atmospheric $\mathrm{CO}_{2}$ on leaf photosynthesis and transpiration, Ann. Bot., 105, 431-442, doi:10.1093/aob/mcp292, 2010.

Kerr, Y. H., Waldteufel, P., Wigneron, J. P., Martinuzzi, J. M., Font, J., and Berger, M.: Soil moisture retrieval from space: The Soil Moisture and Ocean Salinity (SMOS) mission, IEEE T. Geosci. Remote Sens., 39, 1729-1735, doi:10.1109/36.942551, 2001.

Kolari, P., Kulmala, L., Pumpanen, J., Launiainen, S., Llvesniemi, H., Hari, P., and Nikinmaa, E.: $\mathrm{CO}_{2}$ exchange and component $\mathrm{CO}_{2}$ fluxes of a boreal Scots pine forest, Boreal Environ. Res., 14, 761-783, 2009.

Kotani, A., Kononov, A. V., Ohta, T., and Maximov, T. C.: Temporal variations in the linkage between the net ecosystem exchange of water vapour and $\mathrm{CO}_{2}$ over boreal forests in eastern Siberia, Ecohydrology, 7, 209-225, 2014.

Krol, M. C., Peters, W., Hooghiemstra, P., George, M., Clerbaux, C., Hurtmans, D., McInerney, D., Sedano, F., Bergamaschi, P., El Hajj, M., Kaiser, J. W., Fisher, D., Yershov, V., and Muller, J. P.: How much CO was emitted by the 2010 fires around Moscow?, Atmos. Chem. Phys., 13, 4737-4747, doi:10.5194/acp-13-47372013, 2013.

Kurbatova, J., Li, C., Varlagin, A., Xiao, X., and Vygodskaya, N.: Modeling carbon dynamics in two adjacent spruce forests with different soil conditions in Russia, Biogeosciences, 5, 969-980, doi:10.5194/bg-5-969-2008, 2008.

Liu, Y. Y., van Dijk, A., de Jeu, R. A. M., and Holmes, T. R. H.: An analysis of spatiotemporal variations of soil and vegetation moisture from a 29-year satellite-derived data set over mainland Australia, Water Resour. Res., 45, W07405, doi:10.1029/2008wr007187, 2009.

Liu, Y. Y., Parinussa, R. M., Dorigo, W. A., De Jeu, R. A. M., Wagner, W., M. Van Dijk, A. I. J., McCabe, M. F., and Evans, J. P.: Developing an improved soil moisture dataset by blending passive and active microwave satellite-based retrievals, Hydrol. Earth Syst. Sci., 15, 425-436, doi:10.5194/hess-15-425-2011, 2011.

Liu, Y. Y., Dorigo, W. A., Parinussa, R. M., De Jeu, R. A. M., Wagner, W., McCabe, M. F., Evans, J. P., and Van Dijk, A. I. J. M.: Trend-preserving blending of passive and active microwave soil moisture retrievals, Remote Sens. Environ., 123, 280-297, doi:10.1016/j.rse.2012.03.014, 2012.

Mammarella, I., Launiainen, S., Gronholm, T., Keronen, P., Pumpanen, J., Rannik, Ü., and Vesala, T.: Relative humidity effect on the high-frequency attenuation of water vapor flux measured by a closed-path eddy covariance system, J. Atmos. Ocean. Tech., 26, 1856-1866, doi:10.1175/2009jtecha1179.1, 2009.

McGuire, A. D., Anderson, L. G., Christensen, T. R., Scott, D., Laodong, G., Hayes, D. J., Martin, H., Lorenson, T. D., Macdonald, R. W., and Nigel, R.: Sensitivity of the carbon cycle in the Arctic to climate change, Ecol. Monogr., 79, 523-555, doi:10.1890/08-2025.1, 2009.
Milyukova, I. M., Kolle, O., Varlagin, A. V., Vygodskaya, N. N., Schulze, E. D., and Lloyd, J.: Carbon balance of a southern taiga spruce stand in European Russia, Tellus B, 54, 429-442, doi:10.1034/j.1600-0889.2002.01387.x, 2002.

Miralles, D. G.: Evaporation in the global water cycle: Analysing land evaporation using satellite observations $\mathrm{PhD}$, Department of Hydrology and Geo-Environmental Sciences, VU University Amsterdam, Amsterdam, 126 pp., 2011.

Miralles, D. G., De Jeu, R. A. M., Gash, J. H., Holmes, T. R. H., and Dolman, A. J.: Magnitude and variability of land evaporation and its components at the global scale, Hydrol. Earth Syst. Sci., 15, 967-981, doi:10.5194/hess-15-967-2011, 2011a.

Miralles, D. G., Holmes, T. R. H., De Jeu, R. A. M., Gash, J. H., Meesters, A. G. C. A., and Dolman, A. J.: Global land-surface evaporation estimated from satellite-based observations, Hydrol. Earth Syst. Sci., 15, 453-469, doi:10.5194/hess-15-453-2011, 2011b.

Miralles, D. G., Teuling, A. J., Van Heerwaarden, C. C., and De Arellano, J. V. G.: Mega-heatwave temperatures due to combined soil desiccation and atmospheric heat accumulation, Nat. Geosci., 7, 345-349, doi:10.1038/ngeo2141, 2014.

Mittelbach, H. and Seneviratne, S. I.: A new perspective on the spatio-temporal variability of soil moisture: temporal dynamics versus time-invariant contributions, Hydrol. Earth Syst. Sci., 16, 2169-2179, doi:10.5194/hess-16-2169-2012, 2012.

Mladenova, I. E., Jackson, T. J., Njoku, E., Bindlish, R., Chan, S., Cosh, M. H., Holmes, T. R. H., de Jeu, R. A. M., Jones, L., Kimball, J., Paloscia, S., and Santi, E.: Remote monitoring of soil moisture using passive microwave-based techniques - Theoretical basis and overview of selected algorithms for AMSR-E, Remote Sens. Environ., 144, 197-213, doi:10.1016/j.rse.2014.01.013, 2014.

Moffat, A. M., Papale, D., Reichstein, M., Hollinger, D. Y., Richardson, A. D., Barr, A. G., Beckstein, C., Braswell, B. H., Churkina, G., Desai, A. R., Falge, E., Gove, J. H., Heimann, M., Hui, D., Jarvis, A. J., Kattge, J., Noormets, A., and Stauch, V. J.: Comprehensive comparison of gap-filling techniques for eddy covariance net carbon fluxes, Agr. Forest Meteorol., 147, 209-232, doi:10.1016/j.agrformet.2007.08.011, 2007.

Morales, P., Sykes, M. T., Prentice, I. C., Smith, P., Smith, B., Bugmann, H., Zierl, B., Friedlingstein, P., Viovy, N., Sabaté, S., Sánchez, A., Pla, E., Gracia, C. A., Sitch, S., Arneth, A., and Ogee, J.: Comparing and evaluating process-based ecosystem model predictions of carbon and water fluxes in major European forest biomes, Global Change Biol., 11, 2211-2233, doi:10.1111/j.1365-2486.2005.01036.x, 2005.

Muskett, R. R. and Romanovsky, V. E.: Groundwater storage changes in arctic permafrost watersheds from GRACE and insitu measurements, Environ. Res. Lett., 4, 045009, doi:10.1088/1748-9326/4/4/045009, 2009.

Naeimi, V., Scipal, K., Bartalis, Z., Hasenauer, S., and Wagner, W.: An Improved Soil Moisture Retrieval Algorithm for ERS and METOP Scatterometer Observations, IEEE T. Geosci. Remote, 47, 1999-2013, doi:10.1109/tgrs.2008.2011617, 2009.

Naeimi, V., Paulik, C., Bartsch, A., Wagner, W., Kidd, R., Park, S. E., Elger, K., and Boike, J.: ASCAT surface state flag (SSF): Extracting information on surface freeze/thaw conditions from backscatter data using an empirical threshold- 
analysis algorithm, IEEE T. Geosci. Remote, 50, 2566-2582, doi:10.1109/tgrs.2011.2177667, 2012a.

Naeimi, V., Paulik, C., Bartsch, A., Wagner, W., Kidd, R., Sang-Eun, P., Elger, K., and Boike, J.: ASCAT Surface State Flag (SSF): Extracting Information on Surface Freeze/Thaw Conditions From Backscatter Data Using an Empirical Threshold-Analysis Algorithm, IEEE T. Geosci. Remote, 50, 2566-2582, doi:10.1109/tgrs.2011.2177667, 2012b.

Ohta, T., Maximov, T. C., Dolman, A. J., Nakai, T., Molen, M. K. v. d., Kononov, A. V., Maximov, T., Hiyama, T., Iijima, Y., Moors, E. J., and Tanaka, H.: Interannual variation of water balance and summer evapotranspiration in an eastern Siberian larch forest over a 7-year period (1998-2006), Agr. Forest Meteorol., 148, 1941-1953, 2008.

Ohta, T., Kotani, A., Iijima, Y., Maximov, T. C., Ito, S., Hanamura, M., Kononov, A. V., and Maximov, A. P.: Effects of waterlogging on water and carbon dioxide fluxes and environmental variables in a Siberian larch forest, 1998-2011, Agr. Forest Meteorol., 188, 64-75, doi:10.1016/j.agrformet.2013.12.012, 2014.

Oki, T., Imaoka, K., and Kachi, M.: AMSR instruments on GCOMW1/2: Concepts and applications, International Geoscience and Remote Sensing Symposium (IGARSS), Honolulu, Hawaii, USA, 1363-1366, 2010.

Owe, M., de Jeu, R., and Holmes, T.: Multisensor historical climatology of satellite-derived global land surface moisture, J. Geophys. Res.-Earth, 113, F01002, doi:10.1029/2007JF000769, 2008.

Papale, D., Reichstein, M., Aubinet, M., Canfora, E., Bernhofer, C., Kutsch, W., Longdoz, B., Rambal, S., Valentini, R., Vesala, T., and Yakir, D.: Towards a standardized processing of Net Ecosystem Exchange measured with eddy covariance technique: algorithms and uncertainty estimation, Biogeosciences, 3, 571-583, doi:10.5194/bg-3-571-2006, 2006.

Peters, W., Jacobson, A. R., Sweeney, C., Andrews, A. E., Conway, T. J., Masarie, K., Miller, J. B., Bruhwiler, L. M. P., Petron, G., Hirsch, A. I., Worthy, D. E. J., van der Werf, G. R., Randerson, J. T., Wennberg, P. O., Krol, M. C., and Tans, P. P.: An atmospheric perspective on North American carbon dioxide exchange: CarbonTracker, P. Natl. Acad. Sci. USA, 104, 1892518930, doi:10.1073/pnas.0708986104, 2007.

Peters, W., Krol, M. C., van der Werf, G. R., Houweling, S., Jones, C. D., Hughes, J., Schaefer, K., Masarie, K. A., Jacobson, A. R., Miller, J. B., Cho, C. H., Ramonet, M., Schmidt, M., Ciattaglia, L., Apadula, F., Helta, D., Meinhardt, F., di Sarra, A. G., Piacentino, S., Sferlazzo, D., Aalto, T., Hatakka, J., Strom, J., Haszpra, L., Meijer, H. A. J., van de Laan, S., Neubert, R. E. M., Jordan, A., Rodo, X., Morgui, J. A., Vermeulen, A. T., Popa, E., Rozanski, K., Zimnoch, M., Manning, A. C., Leuenberger, M., Uglietti, C., Dolman, A. J., Ciais, P., Heimann, M., and Tans, P. P.: Seven years of recent European net terrestrial carbon dioxide exchange constrained by atmospheric observations, Global Change Biol., 16, 1317-1337, doi:10.1111/j.13652486.2009.02078.x, 2010.

Potter, C. S., Randerson, J. T., Field, C. B., Matson, P. A., Vitousek, P. M., Mooney, H. A., and Klooster, S. A.: Terrestrial ecosystem production: A process model based on global satellite and surface data, Global Biogeochem. Cy., 7, 811-841, doi:10.1029/93gb02725, 1993.
Raich, J. W., Rastetter, E. B., Melillo, J. M., Kicklighter, D. W., Steudler, P. A., Peterson, B. J., Grace, A. L., Iii, B. M., and Vörösmarty, C. J.: Potential Net Primary Productivity in South America: Application of a Global Model, Ecol. Appl., 1, 399429, doi:10.2307/1941899, 1991.

Rannik, U., Keronen, P., Hari, P., and Vesala, T.: Estimation of forest-atmosphere $\mathrm{CO}_{2}$ exchange by eddy covariance and profile techniques, Agr. Forest Meteorol., 126, 141-155, doi:10.1016/j.agrformet.2004.06.010, 2004.

Reichle, R. H. and Koster, R. D.: Bias reduction in short records of satellite soil moisture, Geophys. Res. Lett., 31, L19501, doi:10.1029/2004g1020938, 2004.

Reichle, R. H., and Koster, R. D.: Global assimilation of satellite surface soil moisture retrievals into the NASA catchment land surface model, Geophys. Res. Lett., 32, 1-4, doi:10.1029/2004g1021700, 2005.

Reichle, R. H., Koster, R. D., Liu, P., Mahanama, S. P. P., Njoku, E. G., and Owe, M.: Comparison and assimilation of global soil moisture retrievals from the Advanced Microwave Scanning Radiometer for the Earth Observing System (AMSR-E) and the Scanning Multichannel Microwave Radiometer (SMMR), J. Geophys. Res.-Atmos., 112, D09108, doi:10.1029/2006jd008033, 2007.

Reichstein, M., Falge, E., Baldocchi, D., Papale, D., Aubinet, M., Berbigier, P., Bernhofer, C., Buchmann, N., Gilmanov, T., Granier, A., Grünwald, T., Havránková, K., Ilvesniemi, H., Janous, D., Knohl, A., Laurila, T., Lohila, A., Loustau, D., Matteucci, G., Meyers, T., Miglietta, F., Ourcival, J. M., Pumpanen, J., Rambal, S., Rotenberg, E., Sanz, M., Tenhunen, J., Seufert, G., Vaccari, F., Vesala, T., Yakir, D., and Valentini, R.: On the separation of net ecosystem exchange into assimilation and ecosystem respiration: Review and improved algorithm, Global Change Biol., 11, 1424-1439, doi:10.1111/j.1365-2486.2005.001002.x, 2005.

Reichstein, M., Ciais, P., Papale, D., Valentini, R., Running, S., Viovy, N., Cramer, W., Granier, A., Ogee, J., Allard, V., Aubinet, M., Bernhofer, C., Buchmann, N., Carrara, A., Grunwald, T., Heimann, M., Heinesch, B., Knohl, A., Kutsch, W., Loustau, D., Manca, G., Matteucci, G., Miglietta, F., Ourcival, J. M., Pilegaard, K., Pumpanen, J., Rambal, S., Schaphoff, S., Seufert, G., Soussana, J. F., Sanz, M. J., Vesala, T., and Zhao, M.: Reduction of ecosystem productivity and respiration during the European summer 2003 climate anomaly: a joint flux tower, remote sensing and modelling analysis, Global Change Biol., 13, 634-651, doi:10.1111/j.1365-2486.2006.01224.x, 2007.

Robock, A., Vinnikov, K. Y., Srinivasan, G., Entin, J. K., Hollinger, S. E., Speranskaya, N. A., Liu, S., and Namkhai, A.: The Global Soil Moisture Data Bank, B. Am. Meteorol. Soc., 81, 12811299, 2000.

Schaefer, K., Collatz, G. J., Tans, P., Denning, A. S., Baker, I., Berry, J., Prihodko, L., Suits, N., and Philpott, A.: Combined simple biosphere/carnegie-ames-stanford approach terrestrial carbon cycle model, J. Geophys. Res.-Biogeo., 113, G03034, doi:10.1029/2007jg000603, 2008.

Schepaschenko, D. G., Mukhortova, L. V., Shvidenko, A. Z., and Vedrova, E. F.: The pool of organic carbon in the soils of Russia, Eurasian Soil Sci., 46, 107-116, doi:10.1134/s1064229313020129, 2013. 
Sellers, P. J., Randall, D. A., Collatz, G. J., Berry, J. A., Field, C. B., Dazlich, D. A., Zhang, C., Collelo, G. D., and Bounoua, L.: A revised land surface parameterization ( $\mathrm{SiB} 2)$ for atmospheric GCMs. Part I: Model formulation, J. Climate, 9, 676-705, 1996.

Tarnocai, C., Canadell, J. G., Schuur, E. A. G., Kuhry, P., Mazhitova, G., and Zimov, S. C. G.: Soil organic carbon pools in the northern circumpolar permafrost region, Global Biogeochem. Cy., 23, GB2023, doi:10.1029/2008gb003327, 2009.

van der Molen, M. K., Dolman, A. J., Ciais, P., Eglin, T., Gobron, N., Law, B. E., Meir, P., Peters, W., Phillips, O. L., Reichstein, M., Chen, T., Dekker, S. C., Doubková, M., Friedl, M. A., Jung, M., van den Hurk, B. J. J. M., de Jeu, R. A. M., Kruijt, B., Ohta, T., Rebel, K. T., Plummer, S., Seneviratne, S. I., Sitch, S., Teuling, A. J., van der Werf, G. R., and Wang, G.: Drought and ecosystem carbon cycling, Agr. Forest Meteorol., 151, 765-773, 2011.

van der Velde, I. R., Miller, J. B., Schaefer, K., van der Werf, G. R., Krol, M. C., and Peters, W.: Terrestrial cycling of ${ }^{13} \mathrm{CO}_{2}$ by photosynthesis, respiration, and biomass burning in SiBCASA, Biogeosciences, 11, 6553-6571, doi:10.5194/bg-11-6553-2014, 2014.

Verhoef, A. and Egea, G.: Modeling plant transpiration under limited soil water: Comparison of different plant and soil hydraulic parameterizations and preliminary implications for their use in land surface models, Agr. Forest Meteorol., 191, 22-32, doi:10.1016/j.agrformet.2014.02.009, 2014.

Verstraeten, W. W., Veroustraete, F., Wagner, W., van Roey, T., Heyns, W., Verbeiren, S., and Feyen, J.: Remotely sensed soil moisture integration in an ecosystem carbon flux model. The spatial implication, Climatic Change, 103, 117-136, doi:10.1007/s10584-010-9920-8, 2010.
Vetter, M., Churkina, G., Jung, M., Reichstein, M., Zaehle, S., Bondeau, A., Chen, Y., Ciais, P., Feser, F., Freibauer, A., Geyer, R., Jones, C., Papale, D., Tenhunen, J., Tomelleri, E., Trusilova, K., Viovy, N., and Heimann, M.: Analyzing the causes and spatial pattern of the European 2003 carbon flux anomaly using seven models, Biogeosciences, 5, 561-583, doi:10.5194/bg-5561-2008, 2008.

Vey, S., Steffen, H., Müller, J., and Boike, J.: Inter-annual water mass variations from GRACE in central Siberia, J. Geodesy, 87, 287-299, doi:10.1007/s00190-012-0597-9, 2013.

Wagner, W., Lemoine, G., and Rott, H.: A method for estimating soil moisture from ERS Scatterometer and soil data, Remote Sens. Environ., 70, 191-207, doi:10.1016/s00344257(99)00036-x, 1999.

Way, J., Zimmermann, R., Rignot, E., McDonald, K., and Oren, R.: Winter and spring thaw as observed with imaging radar at BOREAS, J. Geophys. Res.-Atmos., 102, 29673-29684, doi:10.1029/96jd03878, 1997.

Wegmüller, U.: The effect of freezing and thawing on the microwave signatures of bare soil, Remote Sens. Environ., 33, 123 135, doi:10.1016/0034-4257(90)90038-N, 1990.

Williams, M., Richardson, A. D., Reichstein, M., Stoy, P. C., Peylin, P., Verbeeck, H., Carvalhais, N., Jung, M., Hollinger, D. Y., Kattge, J., Leuning, R., Luo, Y., Tomelleri, E., Trudinger, C. M., and Wang, Y. -P.: Improving land surface models with FLUXNET data, Biogeosciences, 6, 1341-1359, doi:10.5194/bg-6-1341-2009, 2009. 